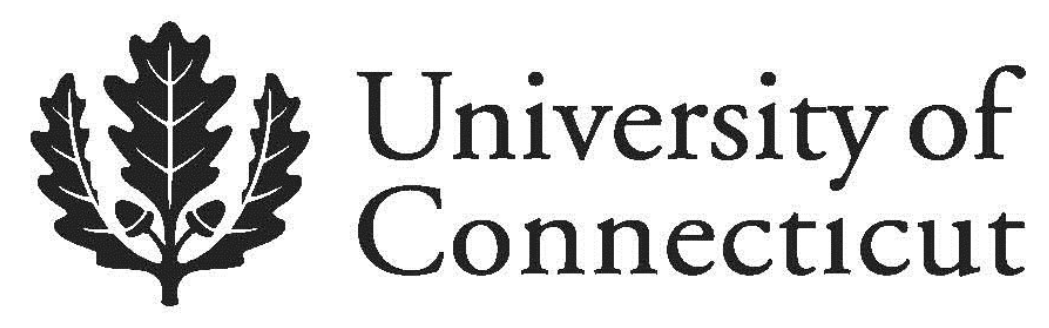

Department of Economics Working Paper Series

\title{
Do Criminal Representatives Hinder or Improve Constituency Outcomes? Evidence from India
}

Nishith Prakash

University of Connecticut

Marc Rockmore

Clark University

Working Paper 2014-20

August 2014

365 Fairfield Way, Unit 1063

Storrs, CT 06269-1063

Phone: (860) 486-3022

Fax: (860) 486-4463

http://www.econ.uconn.edu/

This working paper is indexed on RePEc, http://repec.org 


\title{
Do Criminal Representatives Hinder or Improve Constituency Outcomes? Evidence from India
}

\author{
Nishith Prakash \\ University of Connecticut, IZA, CReAM \& INSIDE* \\ Marc Rockmore \\ Clark University ${ }^{\dagger}$ \\ Yogesh Uppal \\ Youngstown State University
}

August $2014^{\S}$

\begin{abstract}
The recent increase in the number of criminally accused politicians elected to state assemblies has caused much furor in India. Despite the potentially important consequences and the widely divergent views, the implications of their elections to state legislative assemblies on constituency-level economic performance are unknown. Using a regression discontinuity design and data on the intensity of night lights in satellite imagery at the constituency level, our results suggest that the cost of electing criminally accused politicians on measures of economic activity is quite large. Using estimates of the elasticity of GDP to light, we find that the election of criminally accused candidates lead to roughly 5 percent lower GDP growth per year on average. These estimated costs increase for candidates with serious accusations, multiple accusations, and accusations regarding financial crimes. Our result survives variety of robustness checks.
\end{abstract}

JEL Classification: D72, D73, O40, O12

Keywords: Growth, Indian Politicians, Information disclosure, Regression Discontinuity, India

*Assistant Professor, Department of Economics and Human Rights Institute, University of Connecticut, Storrs, CT 06269, USA (e-mail: nishith.prakash@uconn.edu).

${ }^{\dagger}$ Assistant Professor, Department of Economics, Clark University, Worcester, MA 01610, USA (e-mail: mrockmore@clarku.edu).

${ }^{\ddagger}$ Associate Professor, Department of Economics, Youngstown State University, Youngstown, OH 44406, USA (e-mail: yuppal@ysu.edu).

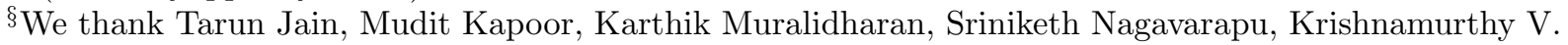
Subramanian, Sandip Sukhtankar and seminar participants at Indian School of Business for helpful comments and discussions. We owe special thanks to Raymond Fisman for sharing his data used in his paper. We especially thank Rajyabardhan Sharma (ex-Indian Police Service) for helping us understand the Indian Penal Code and the ADR Criminal accusation data. We also thank Avijit Ghosh who provided excellent research assistance. We are responsible for any errors that may remain. 
"Earlier politicians used criminals. Now the criminals themselves have entered politics"(Associated Press, 2014)

\section{Introduction}

India is home to the world's largest and the most vibrant democracy, with multiple parties and free elections. At the same time, a very large portion of elected officials have open criminal cases against them. This is contrary to what economic theory predicts, where competitive legislative elections are supposed to prevent criminal or venal candidates from winning or retaining office (Ferraz and Finan, 2011). However, in India, not only are criminally accused politicians elected but this number has steadily increased over time $\frac{1}{12}^{2}$ According to the NY Times (2014), the percentage of elected politicians who have open criminal accusation rose from 24 percent in 2004 to 30 and 34 percent in 2009 and 2014 respectively ${ }^{3}$

With an open and transparent democratic federal structure, India has publicly available information regarding criminally accused representatives $4^{4}$ Consequently, the continued election of such candidates to the national Parliament and state legislative assemblies is not just surprising. While this has been widely discussed, the actual economic costs are unknown to social scientists. It has been well established that political considerations affect the distribution of government transfers, public spending (Albouy, 2009; Ansolabehere and Snyder, 2006; Finan, 2004; Besley et al., 2004) and firms are likely to receive benefits and loans when they are connected to a politician $[5$ Whether the election of criminally accused politicians to

\footnotetext{
${ }^{1}$ An analysis of 541 of the 543 winning candidates in the 2014 Parliamentary elections in India by National Election Watch (NEW) and Association for Democratic Reforms (ADR) suggests that they may even have disproportionate chance to be elected. A candidate with criminal cases had $13 \%$ chance of winning in the 2014 Lok Sabha (Lower House of the Parliament) election whereas it was $5 \%$ for an aspirant with a clean record.

${ }^{2}$ On a constituency-wise basis, 35 percent of all state assembly constituencies (and 45 percent of parliamentary constituencies) feature at least one candidate under serious indictment. Indicted politicians have a 2:1 advantage in terms of winning election, irrespective of the severity of the charges (Vaishnav, 2011).

${ }^{3}$ Article published by Neha Thirani Bagri on May 23, 2014.

${ }^{4}$ It is easy to obtain information on a candidate's criminal record, thus, hiding or under-reporting pending cases is not a serious concern and therefore unlikely to influence elections.

${ }^{5}$ The links between politicians and firms has been widely studied by economists. For example, Khwaja
} 
public offices has impacts on measures of economic activity remains an unanswered empirical question.

Criminality is a well-established problem in India's politics, and all of the major political parties are implicated. The full scope of the problem was not known until after 2003, after public interest litigation by the Association for Democratic Reforms (ADR), an election watchdog, candidates were required to file public disclosures of their backgrounds including any open criminal cases..$^{6}$ Although the phenomenon of "criminal" politicians has been widely publicized, we know very little about the costs of electing such candidates to public offices, whether in India or elsewhere in the developing world. In particular, the constituency level costs, which determine the incentives for and costs of electing such candidates, have not been previously studied $[7$

Three broad explanations have been proposed for the costs of electing criminally accused politicians.

"Every dollar that a corrupt official or a corrupt business person puts in their pocket is a dollar stolen from a pregnant woman who needs health care; or from a girl or a boy who deserves an education; or from communities that need water, roads, and schools. Every dollar is critical if we are to reach our goals to end extreme poverty by 2030 and to boost shared prosperity." - Jim Yong Kim (World Bank President)

The first set of explanations argues that criminally accused politicians are more likely to be criminals and that this adversely affects constituencies. This view is supported by studies which find that voters rejected alleged criminal or corrupt candidates (Banerjee et al., 2014).

and Mian (2005) find that $23 \%$ of firms that received corporate loans in Pakistan had a politician sitting on their board. Fisman (2001) finds that $38 \%$ of firms on the Jakarta stock exchange were closely connected to President Suharto. Faccio et al. (2006) finds that $87 \%$ of market capitalization in Russia is in politically connected firms.

${ }^{6}$ For the detailed discussion of the Supreme Court of India judgement see: http://adrindia.org/sites/ default/files/Supreme_Court's_judgement_2nd_May_2002.pdf

'Asher and Novosad (2013) examine the benefit of having a local politician who is aligned with the party in power of the state government on private sector employment in India. Similarly Sukhtankar (2012) finds that politicians extract rents from firms in order to further their personal electoral goals in the context of state of Maharashtra in India. 
Substantial evidence also supports the idea that criminally accused politicians may have a harmful effect. Corruption, especially regarding public servants, is an ancient problem 8 Corruption has its adverse effects not just on static efficiency but also on investment and growth (Bardhan, 1997). Taking the example of corruption, it has been declared "public enemy number one" by the World Bank and has been linked to lower economic growth, levels of per capita GDP level and Human Development Index scores (Mauro, 1995; Shleifer and Vishny, 1993; Gyiman-Brembong, 2002; Dreher and Herzfield, 2005; Kaufmann, 2002; Rose-Ackerman and Truex, 2012; Olken and Pande, 2012). In the context of India, corruption is not only large in magnitude but also widely pervasive. Recent cases have reported figures of US $\$ 29$ billion in the $20102 \mathrm{G}$ spectrum case and US $\$ 31$ billion for the "Coalgate" scandal between 2004 and 2009. Corruption is sufficiently widespread that the marginal rate of corruption associated with a statutory wage increase in a nationwide scheme (NREGA) was close to 100 percent (Niehaus and Sukhtankar, 2013) $!^{9}$ Recent evidence suggests that corruption is not limited to bureaucrats but also extends to elected representatives (Fisman et al., forthcoming).

"In India's Politics, Jail Time Is a Badge of Honor." - (NY Times, 2014)

A second set of explanations argues that criminally accused politicians are more likely to be criminals but that this is a desired characteristic for voters. Whereas proponents of the first view believe that criminals lead to worse outcomes, supporters of the second view believe that the opposite is true. This might happen for different reasons. Voters may see criminals as being more efficient at finding ways to get money out of the central government (The Star, 2014). In a rapidly growing country with an often centralized allocation of (insufficient) resources, politicians may be able to influence their allocation. For instance, looking at a different aspect of candidates, Nagavarapu and Sekhri (2014) find evidence of

\footnotetext{
${ }^{8}$ Corruption in public administration was documented dating back to the fourth century B.C. in India in Kautiliya's Arthasastra.

${ }^{9}$ While obviously very high, reports in other countries find rates varying from 18 to 87 percent (Reinikka and Svensson, 2004; Olken, 2006; Chaudhury et al., 2006; Olken 2007; and Ferraz et al., 2012.).
} 
regulatory capture since national candidates are able to channel more electricity to their constituencies than do regional candidates.

A closely related idea is that voters may prefer criminal candidates because of patronage. Criminal candidates are both willing and able to make side payments (Wade 1985). In the context of caste-line voting in India, this suggests that criminal candidates may particularly benefit their voters although potentially at some cost for the constituency ${ }^{10}$ In this way, this nuanced view combines both the first and second set of explanations.

"They may protest the administrative machinery and thereby break the law, but they are seen as local heroes who are trying to help poor people by different means" - (NY Times, 2014)

Our analysis is further complicated by a third view which notes that some of the criminally accused candidates may be local "Robin Hoods". Whereas supporters of the first and second view generally agree that the criminally accused candidates are actually criminals, supporters of the third view believe that some of these "crimes" are committed on behalf of the people and therefore that the candidates are not true criminals. For instance, Jaffrerot and Verniers (2014) argue that some cases of criminal behavior are just the result of involvement in democratic protest movements. They note that most - if not all - of the criminal charges against the two candidates with the highest totals (380 and 382 respectively) were due to protests against nuclear power.

If (some of) these candidates are in fact "Robin Hoods", this suggests that the effect of criminally accused candidates on constituency level outcomes remains an open empirical question. As the proportion of "Robin Hoods" increases, the effect of criminally accused politicians should tend towards zero and eventually lead to positive outcomes.

One potential problem is that the impact of criminally accused candidates on light output (and proxy for economic growth) is likely to be endogenous to the outcome variable of interest. In particular, the constituencies that elect criminally accused candidates may differ

\footnotetext{
${ }^{10}$ Vaishnav (2011) argues that criminally indicted politicians benefit parties when they can exploit social divisions to build a compelling case that their criminality gives them an advantage in serving the interests of their fellow co-ethnics.
} 
in unobserved ways from constituencies that elect candidates who are not criminally accused. In this paper, we use a regression discontinuity design (RDD), and compare constituencies in which a criminally accused candidates barely won with constituencies in which a criminally accused candidate barely lost (to a non-criminally accused candidate) in state assembly elections in India between 2004 and 2008. The underlying assumption is that if these elections are close enough to swing for either candidate, they provide nearly random variation in the identity of the winning candidate (Lee, 2008; Lee and Lemieux, 2010). The use of an RDD design to resolve endogeneity in elections is not novel in the context of India as it has been exploited by several recent studies (Asher and Novosad, 2013; Fisman et al., forthcoming; Bhalotra et al., 2013; Bhalotra et al., 2013; Clots-Figueras, 2012; Bhalotra and Clots-Figueras, 2014; Uppal, 2009).

Our main findings indicate that at the cutoff criminally accused candidates who are elected have a causal and strong negative impact on the growth of night light at the constituency level. Using global (Henderson et al. 2012) and India-specific (Bickenbach et al. 2013) estimates of the elasticity of GDP to night light, we find that criminally accused candidates lead to an average $2.7 \%$ to $7.6 \%$ lower GDP growth per year. Using an average GDP growth rate of $6 \%$ per year, the findings show that yearly growth was 0.29 to 0.81 GDP points lower per year.

This study is of interest for several reasons. Foremost, we present the first quantitative estimates of the economic costs of electing criminally accused politicians to state assemblies by focusing at the constituency level economic growth. The results suggest strong costs to local economic growth which would likely spill over onto other outcomes such as poverty. Moreover, they highlight a potential cost associated with the election of lower quality (or criminal) candidates in democracies. Since there is no time series data of economic growth at the constituency level, we use the intensity of night lights in satellite imagery as a proxy for local economic growth. Additionally, our paper also contributes to an emerging literature on how various political factors affect distribution of night lights in India. Baskaran, 
Min and Uppal (2014) find that in special elections to state legislative Assemblies held to fill midterm vacancies electricity provision increases just before elections. The electricity targeting appears more pronounced in swing races and where government majority is at stake.

To test the robustness of our main findings and due to the specific context in India, we further examine different definitions of "criminal" accusations. This is especially important because court cases in India can take decades, opposing candidates may have incentives to file false cases against each other ${ }^{11}$ We first, use "serious" charges and show that our main findings are not only significant but of larger magnitude. The choice of "serious" charges is motivated by several reasons. As noted earlier, democratic reformers tend to be accused of less serious charges such as unlawful assembly, civil disobedience, electioneering, etc. Additionally, clearly not all accusations (if true) are likely to affect the economic outcomes in a constituency with more serious charges likely indicating a stronger effect. Additionally, insofar as it is costlier to manufacture serious charges, such as murder, kidnapping or rape, against an opposing candidate, the "serious" may be more likely to be true. We then consider different thresholds of "multiple" criminal charges. Insofar as there is cost to falsely accusing opponents, higher number of accusations should give a stronger signal. We finally consider "financial" charges, where we consider charges that causes loss to public exchequer. Once again our main findings are robust but of larger magnitude. It is important to consider various categories, because not all criminal accusations are equal when considering their impact on measures of economic activity. To sum up, our main findings are robust to these alternative definitions but the magnitude of the coefficient increases.

Taken together, our results indicate that criminally accused politicians have a strong adverse impact on constituency level growth. This is consistent with both the first view (they harm the constituency) and the more nuanced version of the second view (they harm

\footnotetext{
${ }^{11}$ Vaishnav (2011a) conducts three tests of political motivation and reject the hypothesis that cases are disproportionately filed against politically prominent or successful candidates.
} 
the constituency but benefit particular voting blocks). To differentiate between these views, we investigate the distribution of night lights between constituencies which elect criminallyaccused candidates and those without charges. Our admittedly crude measure of criminal status does not indicate any difference between candidate types.

The remainder of this paper is organized as follows. Section 2 provides detailed description of the institutional context. Section 3 discusses the identification strategy while section 3 describes the data. Section 5 presents the results on the costs of electing criminally accused candidates and discusses robustness. Section 6 concludes and discusses the policy implications.

\section{Background}

\subsection{Political Institutions in India}

India is a federal republic with a parliamentary system of government, where the formal political structure parallels that of the national structure. The Parliament of India consists of the President of India and the two Houses - The Upper House (also called the Rajya Sabha or Council of States) and The Lower House (also called the Lok Sabha or House of the People). Those elected or nominated to either house of the Parliament are referred to as Members of Parliament (or MPs). The states in India follow a similar structure where The Upper House is called Vidhan Parishad (or Legislative Council) and The Lower House is called the Vidhan Sabha (or Legislative Assembly). Those elected or nominated to either house of the state assembly are referred to as Member of Legislative Assembly (or MLAs).

Both federal and states are divided into a single-member constituencies and characterized by a first-past-the-post election system. That is, in each constituency, the candidate with the plurality of votes wins the elections. Elections are scheduled to take place every 5 years;

although it is possible to have elections before the 5-year term mostly due to shifting of 
political alignments 12

\subsection{Criminality in Indian Politics}

The issue of criminally accused candidates contesting elections in India is not new. Both the Election Commission of India and the Indian Parliament have shown great concern about the increasing "criminalization" of politics, especially after the landmark judgment of the Supreme Court of India in 2003. The Association for Democratic Reforms (ADR) along with the National Election Watch have conducted Election Watches for all State and Federal elections post 2003 in India. ${ }^{13}$

It is widely believed that there is a criminal nexus between political parties and anti-social elements leading to increased criminalization of politics in India. In the recently concluded Lok Sabha Elections, roughly one third of the newly-elected MPs have a criminal background according to their disclosed sworn affidavits to the Election Commission of India. In total, 186 out of 543 Members of Parliament (MP) have criminal cases including serious charges of murder and rape. What is surprising is that the proportion of MPs facing criminal charges has increased between the 2009 and 2014 Lok Sabha elections ${ }^{14}$ The story is similar for the state legislative assembly elections. According to the ADR report, over $30 \%$ of the MLAs face criminal cases in India.

For example, in one of most populous and politically important state, Uttar Pradesh, 575 candidates for the 403 assembly seats had criminal backgrounds or faced criminal charges during the 2007 state legislative assembly elections. Out of these 403 candidates, 140 won assembly seats. Following this success, it is not surprising that an even greater number of

\footnotetext{
${ }^{12}$ According to the Indian Constitution, any Indian citizen who is registered as a voter and is over the age of 25 years can run for election to the Federal; Government or the State Legislative Assemblies. However, candidates running for the State Legislative Assemblies should be the resident of the same state.

${ }^{13}$ Election Watch comprises background reports based on Criminal, Financial, Educational and Income Tax details of Candidates and Winners (MPs, MLAs and Ministers) who have contested Elections to State Assemblies, the Parliament and a few local bodies.

${ }^{14}$ In 2009, 30\% of the Lok Sabha members or MPs had criminal cases and this share has increased to $34 \%$ in the last concluded Lok Sabha elections in 2014.
} 
criminally accused candidates (759) ran in the next elections in 2012. Of these, 189 won seats in the state assembly. (ADR 2012a).

Elected officials, including MPs and MLAs are widely reputed to be involved in corruption, mostly graft and embezzlement of public funds (BBC News India 2012, India Today 2012). In the case of Uttar Pradesh state legislators, the 287 elected MLAs in 2007 who ran for elections again in 2012 witnessed an increase in their average asset value from $\$ 220,613$ to $\$ 658,804$, over their 5 year term in office. The political affiliation was especially important as MLAs who belonged to the political party heading the state government (or the ruling party) saw their asset value increase to an average of $\$ 500,000$. For opposition party members, this increase amounted to less than $\$ 300,000$ (Banerjee et. al 2012) ${ }^{15}$

Moreover, Fisman et al. (forthcoming) utilize the asset disclosures of candidates for Indian state legislators taken at two points across a five year election cycle and compares the asset growth of election winners versus runners-up to calculate the financial returns from holding public office relative to private sector opportunities available to political candidates. The estimated annual growth rate of winners' assets is 3-5 percent higher than that of runners-up.

\section{Empirical Strategy}

This paper considers assembly elections held during the 2004 to 2008 period to examine whether the impact of electing a criminally accused candidate on economic performance in the constituency. We consider the following model:

$$
y_{i s t+1}=\alpha+\beta * C R I M I N A L_{i s t}+\varepsilon_{i s t+1}
$$

\footnotetext{
${ }^{15}$ The average annual salary of MLAs in Uttar Pradesh is approximately $\$ 12,000$. The Chief Minister (elected head of the state) of Uttar Pradesh, Kumari Mayawati, saw her wealth increase $\$ 6.2$ million over her five-year term from 2007-2012. Data were downloaded from National Election Watch (http://www.myneta.info), which compiles information from affidavits submitted by candidates during the nomination process.
} 
where $y_{i s t+1}$ represents economic performance of constituency $i$ in state $s$ in year $t+1$. In the absence of direct measures of economic performance, we follow the literature and use the light output as a proxy. $C R I M I N A L_{i s t}$ is an indicator variable for treatment, which is 1 if a constituency $i$ in state $s$ elects an MLA with a criminal background and 0 otherwise. Also, $\varepsilon_{i s t+1}$ is the stochastic error term.

If the criminal status of an MLA was randomly assigned, constituencies that elected a non-criminal MLA will serve as a valid counterfactual for constituencies that elected a criminal MLA and we could compare average outcomes in these two types of constituencies to identify the causal effect of electing a criminal candidate:

$$
E\left[y_{i s t+1} \mid C R I M I N A L_{i s t}=1\right]-E\left[y_{i s t+1} \mid C R I M I N A L_{i s t}=0\right]=\beta .
$$

However, we doubt that the criminal status of an MLA is randomly determined. The main concern is that due to unobserved heterogeneity, constituencies with criminal candidates may not be comparable to constituencies without criminal candidates. For instance, criminal candidates may be more likely to run and win from certain constituencies than others. As a result, $\beta$ does not identify the causal effect of criminal status of an MLA and is biased as the condition $E\left[\varepsilon_{i s t+1} \mid C R I M I N A L_{i s t}\right]=0$ does not hold.

$$
\begin{gathered}
E\left[y_{i s t+1} \mid C R I M I N A L_{i s t}=1\right]-E\left[y_{i s t+1} \mid C R I M I N A L_{i s t}=0\right]= \\
\beta+E\left[\varepsilon_{i s t+1} \mid C R I M I N A L_{i s t}=1\right]-E\left[\varepsilon_{i s t+1} \mid C R I M I N A L_{i s t}=0\right]
\end{gathered}
$$

We, however, exploit the discontinuity that arises in the first-past-the-post electoral systems. By the electoral law, only candidates who get the most votes and have a positive victory margin (defined as the difference in the vote shares of the winner and runner-up candidates) become elected. We compare criminal winners and criminal losers in close elections, where the winner's margin of victory is arbitrarily small and hypothesize that in such 
close contests election of an MLA with criminal background is decided as if it is random. In other words, constituencies in which a criminal candidate barely lost could serve as a valid counterfactual for constituencies that barely elected a criminal MLA allowing us to estimate the difference in outcomes of such constituencies as the causal effect of criminal background of an MLA. More formally, define reservation status as follows:

$$
\begin{aligned}
\text { CRIMINAL }_{\text {ist }} & =1 \text { if MARGIN } \text { ist }>0 \\
& =0 \text { if } M A R G I N_{i s t}<0,
\end{aligned}
$$

where $M A R G I N_{i s t}$ is the margin of victory of an MLA. By construction, it is positive for a criminal MLA, the treated group, and negative for a non-criminal MLA, the control group. At a margin of zero, criminal status of an MLA changes discontinuously from non-criminal to criminal. Consider contests within a close neighborhood $\lambda$ of the threshold margin of zero.

$$
\begin{gathered}
E\left[y_{i s t+1} \mid 0<M A R G I N_{i s t} \leq \lambda\right]-E\left[y_{i s t+1} \mid-\lambda \leq M A R G I N_{i s t}<0\right]= \\
\beta+E\left[\varepsilon_{i s t+1} \mid 0<M A R G I N_{i s t} \leq \lambda\right]-E\left[\varepsilon_{i s t+1} \mid-\lambda \leq M A R G I N_{i s t}<0\right] .
\end{gathered}
$$

The RD design argues that as $\lambda$ goes to 0 , i. e. as we examine closer elections, the differences between criminal and non-criminal constituencies vanish and we identify the causal effect of criminal status.

$$
\lim _{\lambda \rightarrow 0^{+}} E\left[y_{i s t+1} \mid 0<M A R G I N_{i s t} \leq \lambda\right]-\lim _{\lambda \rightarrow 0^{-}} E\left[y_{i s t+1} \mid-\lambda \leq M A R G I N_{i s t}<0\right]=\beta,
$$

which is simply the difference in the average outcomes of constituencies that barely elected a criminal MLA and constituencies that barely elected a non-criminal MLA. 


\section{Data}

\subsection{Criminal Status}

Beginning in 2003, candidate contesting elections for elected bodies in India were required to submit an affidavit detailing his or her criminal background, asset information and educational qualifications to the Election Commission of India (ECI). These affidavits are publicly available on the Commission's website. The Association for Democratic Reforms (ADR), an election watchdog, has compiled information from these affidavits ${ }^{16}$ This data provides information about the number and type of criminal accusations against a candidate, number of convictions, total assets, both moveable and immoveable, of a candidate, a candidate's educational qualifications, and his or her profession.

While we use all of the information on candidates, we are primarily interested in the information regarding criminal accusations. In particular, we create a binary variable for whether a candidate is accused of any crime. It takes a value of 0 if MLA has any accusation and 0 otherwise.

As noted in the introduction, the data on criminal accusations may be misleading for a variety of reasons. In particular, beyond high profile political vendettas between leading politicians, the notoriously slow pace of the Indian judicial system provides an incentive for opponents to arrange for false criminal accusations. Similarly, there is no reason to believe that all types of criminal accusations (or crimes) will have a similar impact on economic performance. Even if the accusations are true, the importance of political or financial accusations is likely very different than those related to say driving. Additionally, some cases of criminal behavior are just the result of involvement in democratic protest movements.

For these reasons and others, it is important to consider different definitions of criminal accusations. If there is some cost to arranging for false criminal accusations, candidates with

\footnotetext{
${ }^{16}$ The ADR data is available for public use at www.myneta.info. A sample affidavit is included in the appendix.
} 
higher numbers of criminal accusations are more likely to have "true" criminal accusations. That is, the veracity of the signal (criminal cases) increases with the number of cases. Consequently, we also consider an alternate definition for criminal accusation where the threshold for being coded as being criminally accused is raised to two or more crimes (irrespective of whether it is the same crime). Since this threshold is arbitrary, we also consider more restrictive threshold of 5 cases.

Similarly, we use the information on the type of crimes to separate "serious" crimes from less serious ones. Since any classification would be arbitrary, we follow the ADR classification between serious and non-serious crimes. While the full list of Indian Penal Codes (IPC) and their division between serious and non-serious are available in the online appendix, ADR divides crimes based on criteria such as the maximum punishment under the law, their violent nature, and offenses under the Prevention of Corruption Act.17 Using this information, we create a binary variable for being accused of any serious crimes as defined by ADR. Lastly, we examine financial crimes by creating a binary variable which takes a value of 1 for any individual accused of any crimes related to corruption or financial gains from the state. By looking at the candidates accused of financial crimes, we are able to isolate candidates that are accused of crimes causing a loss to public exchequer 18

It is unfortunately not possible to identify which criminal accusations arise from democratic protest movements or similar activity. Since accusations arising from democratic protests are "falsely" coded as criminal activity, this would suggest that this will lead to classical measurement error and our estimates of the effects of "true" criminal accusations will be biased towards zero.19

Since the RD design uses criminally accused losers as the counterfactual, this implies

\footnotetext{
${ }^{17}$ The following is a link to an online Appendix on ADR criteria for coding serious crimes: http:// adrindia.org/content/criteria-categorization-serious-criminal-cases .

${ }^{18}$ We consider the following IPCs as financial crimes after discussing with an ex-IPS Officer: 171B, 171E, 230-262, 272, 273, 274, 275, 276, 378-420, and 466-489D. Explanation of the particular IPCs is available on: http://adrindia.org/content/criteria-categorization-serious-criminal-cases.

${ }^{19}$ Vaishnav (2011a) conducts three tests of political motivation and reject the hypothesis that cases are disproportionately filed against politically prominent or successful candidates.
} 
that the choice in the constituency where the criminally-accused MLA won was between the two types of candidates. This is not necessarily the case as constituencies may be choosing between only criminally accused candidates. We therefore restrict the sample to constituencies where the two candidates are one criminally-accused and one non-criminal accused candidate. This restricts our sample from the full 2633 constituencies for which we have data to a smaller sample of 94120

\subsection{Dependent Variable}

While we are interested in the economic activity at the constituency level, this information is not widely available across constituencies or time. Following Henderson et al. (2012) and others, we use the intensity of night light as a proxy for economic activity. Henderson et al. (2012) and Storeygard (2014) show that there is a strong relationship between GDP and night light intensity at the sub-national level using a cross-section of countries for the world and Sub-Saharan Africa, respectively. Bickenbach et al. (2014) validate the use of the measure for India using district level data. As we describe below, the night light data is available annually and can be disaggregated at lower level administrative or political units.

The satellite images come from the National Aeronautics and Space Administration's (NASA) Defense Meteorological Satellite Program's Operational Linescan System (DMSPOLS), a set of military weather satellites that have been flying since 1970 in polar orbit recording high resolution images of the entire earth each night between 20:00 and 21:30 local time. The high resolution images, captured at an altitude of $830 \mathrm{~km}$ above the earth, record concentrations of outdoor lights, fires, and gas flares at a fine resolution of $0.56 \mathrm{~km}$ and a smoothed resolution of $2.7 \mathrm{~km}$. These images are available from 1992 onwards and are used to produce annual composites during a calendar year, dropping images where lights are shrouded by cloud cover or overpowered by the aurora or solar glare (near the poles), and

\footnotetext{
${ }^{20}$ Note that all of our results are robust to using the full sample. We choose this restricted sample since this is the implicit comparison in our RD design.
} 
removing ephemeral lights like fires and other noise.

The result is a series of images covering the globe for each year from 1992 to 2009 (Elvidge et al. 1997, 2001). Images are scaled onto a geo-referenced 30 arc-second grid (approximately $1 \mathrm{~km} 2)$. Each pixel is encoded with a measure of its annual average brightness on a 6-bit scale from 0 to 63 . We utilize the data available on stable night lights that drop light values from pixels with unstable light signatures over time.

The satellite imagery also provide an objective source from which economic activity can be tracked. Panels A and B in Figure 1 show satellite images of Indian subcontinent in 1992 and 2009. India appears substantially more lit in 2009 than in 1992. This period immediately follows the beginning of the economic reforms in 1991. These reforms transformed an economy that was in an external debt crisis to an economy that was one of the fastest growing economies in the world. More importantly, this transformation is captured by the nighttime imagery in terms of growing light output over the same period.

Our primary dependent variable is the rate of growth of light output. This is the change in the natural log of night light intensity for the constituency between the current and previous period. As noted earlier, this has been widely accepted in the literature as a proxy for economic activity. By specifying it in this manner (i.e. the difference in natural logs), it will allow us to get a rough estimate of the impact on GDP using estimates of the elasticity of GDP growth to night light growth from the literature.

\subsection{Constituencies}

While the night light data begins in 1992 and the election data in 2003, we are unable to use the full data. The data on night lights needs to be aggregated up to the constituency level. While the boundaries for constituencies were fixed in 1976, these were affected by the Delimitation Act of 2002. This act constituted a delimitation commission to redraw the constituency boundaries based on the 2001 census figures. Based on the delay in compiling the necessary data and in creating the new boundaries, the first election with redrawn boundaries 
was only held in Karnataka in 2008. Consequently, the period between 1976 and 2008 had fixed constituencies boundaries allowing for the comparison of satellite imagery across time. Once the new boundaries were implemented, it is not possible to make comparison between the two periods. Thus, between the Court order to file affidavits in 2003 and redrawing of boundaries in 2008, we observe only 1 election per state.

Also, ADR does not compile affidavit information for elections held right after the order was passed and reports this information starting from elections held in states of Arunachal Pradesh, Maharashtra, and Orissa in 2004. The states excluded from our analysis are Andhra Pradesh, Chhattisgarh, Jammu and Kashmir, Karnataka, Madhya Pradesh, Mizoram, Rajasthan, and Sikkim. Table 1 reports the states that we include in our study, which is 20 out of a total of 28 states that held an election between 2004 and 2008. Table ?? reports descriptive statistics of the main variables we use in our analysis.

\section{$5 \quad$ Empirical Results}

\subsection{Main Results}

Visually, our primary result is apparent in Figure2, which plots the growth of light against the margin of victory (margin) for criminally accused candidates. The scatter plot is local averages of growth of light in each successive interval of $0.5 \%$ of margin of victory. The solid curves are plotted non-parametrically using local linear regression which uses a rectangular kernel and a bandwidth using the optimal bandwidth criterion proposed by Imbens and Kalyanaraman (2012). Positive margins of victory indicate a constituency in which the criminally accused candidate won against a non-accused candidate while a negative margin shows that she/he was the runner-up and that the winner was not criminally accused. The criminal status changes discontinuously at margin $=0$.

Panel (a) and (b) plot the growth of light, without and with state and year fixed effects respectively. In both panels, there is a clear difference in the growth of light at the dis- 
continuity (margin=0). This vertical difference between the red and blue lines reflects the causal effect of electing a criminally accused candidate. In particular, at the threshold, there is a clear negative effect of electing a criminally accused candidate although its magnitude decreases somewhat with the inclusion of state and year fixed effects (panel b).

Quantitatively, these estimates are reflected in Table 3 column 1, which shows the estimated effects using non-parametric fit (as in the Figure 2) ${ }^{21}$ Criminal is a dummy variable that is 1 if a criminally accused candidate wins against a non-accused candidate and 0 if criminally accused candidate loses against a non-accused candidate. Since criminal background information is filed in an affidavit at the time of the election and light data is annual, the criminal dummy is fixed for the entire term of the election. Since light output is likely to be correlated overtime within a constituency, the standard errors are clustered at the constituency level. Also, we consider specifications with and without state and year fixed effects.

In Panel A, a criminally accused MLA has a significant negative effect on growth of light in a constituency. In Panel B, we account for state and year fixed effects as the dependent variable is residuals from a regression of growth of light on state and year dummies. The estimated coefficient is slightly smaller after we account for state and year fixed effects. The effect of electing a criminally accused politician is negative and statistically significant at the $5 \%$ level. Substantively, constituencies that barely elect a criminally accused candidate experience about 25 percentage point decline in growth of light compared to constituencies in which a criminally accused candidate barely loses.

While we investigate the robustness of the results in Section 5.3, the main results indicate that criminally accused politicians have strong adverse impact on the economic growth at the constituency level, as proxied by the growth of night light intensity. In terms of the widely divergent views surrounding the debate on criminally accused politicians, this is consistent with the first view (they harm the constituency) and the more nuanced version of the second

\footnotetext{
${ }^{21}$ The procedure used to estimate the size of discontinuity is as described in Nicols (2012).
} 
view (they harm the constituency but benefit particular voting blocks). These finding appear to strongly contradict the view that these candidates help the constituency. These results do not contradict the idea that certain criminally accused candidates are unfairly accused or that they may become accused as a result of helping the community (the third view). However, they do show that on average these candidates have a negative impact.

\subsection{Heterogeneity in Costs of Electing Criminally Accused Politi- cians}

Thus far, we have focused on estimating the average costs of electing criminally accused politicians around the discontinuity. In Table 4, we allow the effect to vary by various observable characteristics (Table 9 presents the parallel results using the fourth order polynomial).

First, we allow the effects to vary by the so-called BIMAROU (Bihar, Chhattisgarh, Jharkhand, Orissa, Uttar Pradesh and Uttarakhand) and Non-BIMAROU states. The reason we classify states as BIMAROU is because they have more corrupt constituencies (see Fisman et al. for detailed discussion) and they are known to have weaker institutions. ${ }^{22}$ Since the 1980's these states have been singled out for corruption and for being dysfunctional (these are also the Hindi speaking belt). Additionally, there exists high degree of correlation between the Transparency International State-level measure and the BIMAROU classification. The estimated coefficient is presented in Table 4, column 1 for the BIMAROU states and in column 2 for the Non-BIMAROU states. As expected the size of the estimated coefficient for the BIMAROU states is larger and statistically significant in column 1 as compared to the coefficient in Table 3, column 1. However, the results are not statistically significant for Non-BIMAROU states.

We further divide the sample into non-reserved, SC, and ST constituencies. So far we have

${ }^{22}$ The Man Who Coined the term BIMARU: http://www.business-standard.com/article/
current-affairs/ashish-bose-the-man-who-coined-bimaru-tried-to-make-things-simple-114040701234_
1.html


argued that it is the criminality of the politician that is driving our main results. If this is true then it is worth investigating how the effects vary by types of constituencies. According to Vaishnav (2011), the criminality rate is approximately $27 \%$ in SC constituencies, $18 \%$ in ST constituencies, and $40 \%$ in non-reserved (also referred as General) constituencies. In addition, compared to non-reserved constituencies, SC/ST constituencies have a very small percentage of multiple indicted candidates competing against each other ${ }^{23}$ Lastly, reserved constituencies differ from non-reserved constituencies in several dimensions, including socioeconomic characteristics, demographics, and plausibly rewards to holding public office could be lower.

We present the costs of electing criminally accused politicians by reservation status of constituencies in columns $3-5$. It seems obvious that it is the criminality of the candidate in non-reserved constituencies that is driving our results. The estimated coefficient is larger and statistically significant for non-reserved constituencies as compared to SC and ST constituencies. However, the sample size is much smaller for SC and ST constituencies and hence we are left with lower statistical power.

For future research, it is will be worth dividing the non-reserved constituencies by candidate's caste, especially the other backward class (OBC) ${ }^{24}$ OBCs have played an active role in Indian politics especially in the BIMARU states and their rise has been well documented by social scientists (see Routledge Handbook of Indian Politics, edited by Kohli and Singh, 2013; Jaffrelot, 2000 for detailed discussion.). Moreover, in the last two decades, Indian politicians have successfully used social engineering to create several caste groups with the

\footnotetext{
${ }^{23}$ According to Vaishnav (2011), roughly $17 \%$ of General constituencies exhibit criminal competition, while this number is only $6 \%$ in $\mathrm{SC}$ constituencies and $5 \%$ in $\mathrm{ST}$ constituencies.

${ }^{24}$ Other Backward Class (OBC) is a collective term used by the Government of India to classify castes which are educationally and socially disadvantaged. In the Indian Constitution, OBCs are described as "socially and educationally backward classes", and the Government of India is enjoined to ensure their social and educational development-for example, the OBCs are entitled to $27 \%$ reservations in public sector employment and higher education. The list of OBCs maintained by the Indian Ministry of Social Justice and Empowerment is dynamic, with castes and communities being added or removed depending on social, educational and economic factors. Under Article 340 of the Indian Constitution, it is obligatory for the government to promote the welfare of the OBCs.
} 
OBCs category for vote-bank politics that requires further in-depth analysis ${ }^{25}$

\subsection{Validating the RDD}

The main assumption of the RD design is that the characteristics of both candidates and constituencies are continuous around the discontinuity. That is, while the characteristics for criminally accused and non-accused candidates may be different over the entire sample, they should be identical at the discontinuity. While every possible characteristic cannot be examined, the available data strongly suggest that the characteristics are continuous.

We formally check for continuity of various constituency characteristics in Figure 3. In Panels (a)-(n), we compare bare criminal winners and bare criminal losers on growth of light in the prior year and on several other candidate and constituency characteristics, such as the assets and liabilities of the winner and 1st runner-up as reported in the affidavits filed with the election commission; their educational attainment; gender; electorate size in the previous election, which is the number of registered voters, and number of voters in the previous election, which is the number of registered voters who actually voted; whether a constituency was aligned with the ruling state party; and whether a constituency is reserved for Scheduled Caste (SC) or Scheduled Tribes (ST). We plot residuals from the regression of each of these variables on state dummies and hence account for state fixed effects. As for the main effects, we plot both local averages and local linear regression fits against margin of victory. These predetermined variables vary fairly continuously with margin of victory. Any apparent discontinuities are highly insignificant. The continuity of all these characteristics suggests that the causal effect of criminal status of a constituency in this paper is not an artifact of heterogeneity across criminal and non-criminal constituencies.

One further concern when an RD design is that close elections may sort candidate around the cutoff. For instance, perhaps candidates know that elections in a particular constituency

\footnotetext{
${ }^{25}$ http://timesofindia.indiatimes.com/india/Nitishs-social-engineering-formula-inspires-Congress/ articleshow/11653704.cms
} 
are close and therefore criminally accused candidates rig the election to win. If this were the case, this would suggest that we would find a larger frequency of criminally accused candidates around the margin (since they would rig the elections and beat clean candidates). This would imply that the density of the margin of victory, the running variable, would show a discontinuity at the cutoff. Figure 4 show the result of a McCrary Density test (2008) which confirms that the density of the running variable is similar immediately above and below the cutoff. Taken together these checks strongly support our use of an RD design.

\subsection{Robustness Checks}

This section examines the robustness of the above results. We first examine issues related to the primary variable of interest (being criminally accused). Second, we validate the main results using alternative definition of dependent variable and finally we present the main results using an alternative functional form, i.e. on a fourth-order polynomial in margin of victory and the interaction of the polynomial terms with the criminal dummy. As we show below, the results are robust to alternate definitions of the variables of interest and the alternative functional form.

\subsubsection{Examining "Criminally Accused"}

As discussed earlier, there are a variety of reasons to believe that the data on criminal accusations should be examined more closely. Consequently, in Table 5, we use the alternate specifications as discussed earlier. The first column uses the binary variable for any accusation for a serious crime, while the second column uses a binary variable for any accusation of a non-serious crime. We also distinguish the results by financial and non-financial crimes. The subsequent columns use progressively higher thresholds for criminal accusation, 2 and 5 , respectively.

While the results presented in Table 5 show that our results are robust to different specifications of being criminally accused, they also raise the question about what type of 
criminal accusations matter? That is, should all accused candidates be regarded in the same manner or does the type of accusation matter?

When we examine different types of accusations, we find that the specific charge matters greatly. For example, the estimated impact of "criminal accusations" remain significant but the magnitude of the coefficient increases when we examine the effect of "serious" accusations in column 1 or higher numbers of accusations in column 5-6. Thus, we find that certain types of accusations lead to (much) higher costs to constituencies.

However, not all accusations lead to a negative impact. In particular, when we examine candidates who have been accused of a non-serious crime (column 2) or who have been accused of a non-financial crime (column 4), not only is the estimated magnitude much smaller but also not statistically significant. This suggests that certain accusations matter more than others and underlie our primary results.

Unfortunately, the available data do not allow us to distinguish whether this is because certain accusations are more likely to be true (i.e. they are criminals) or whether they proxy for some underlying characteristic of the candidate.

\subsubsection{Examining Measurement of Light}

In this sub-section we examine one potential concern regarding the dependent variable. So far we have been looking at the year to year variation in the growth night light in a constituency which could potentially be influenced by year to year volatility.

We therefore consider an alternate measure where we consider the growth of light averaged over the entire period (i.e. the election term) and present the results in Table 6, column 1. We find that the growth of night light remains significant when we estimate without (Panel A) and with state and year fixed effects (Panel B) although the estimated coefficient drops. 


\subsubsection{Alternative Specification}

In this sub-section we estimate our main results using an alternative specification. In particular, we estimate the effects using a $4^{\text {th }}$ order polynomial fit, where it is a $4^{\text {th }}$ order polynomial in the margin of victory and interactions of polynomial terms with the binary variable for being criminally accused. The polynomial is then evaluated at the threshold margin 0. This is equivalent to the estimated coefficient on the binary criminal accused variable in the $\mathrm{RD}$ with a parametric fit.

The main results are presented in Table 3, column 2. We further present the results for the alternate definition of criminally accused in Table 7 and for alternate measure of night light in Table 6, column 2. Finally we present the results for the heterogeneity in Table 9.

For the baseline result, we find that the point estimate decreases with the fourth of the polynomial but is not significantly different from the reported baseline coefficient (Table 3 , columns 1). To sum up, our findings are robust to the estimation of this alternative functional form.

\subsection{Economic Implications}

As we show in the preceding sections, the negative average effect of electing criminally accused politicians is extremely robust. While we use the change in night light intensity as a proxy for economic activity, it is possible to obtain a rough estimate of the direct effect by using the elasticity for the effect of night light intensity on GDP growth. We use two alternate measures. We use the elasticity estimated by Henderson et al. (2012) (roughly 0.30) since this is the main paper on topic. Since this is a rough estimate and uses a wide variety of countries, we also use Bickenbach et al.'s (2014) India specific estimate of elasticity (0.107). These two estimates give us an upper and lower bound respectively for the effect on GDP growth.

Table 8 presents these results using the coefficient for the base results as well as from 
the robustness checks for the "criminally accused" variables ${ }^{26}$ In each case, we use the specification with state and year fixed effects which are likely more accurate. Depending on the specification, we find estimates ranging from 2.7 to 7.6 percent lower GDP growth per year. India experienced very high growth during this period. Since these are estimates of the yearly cost, the foregone growth over the entire term is larger as these losses compound over the full 5 year term. Using 6 percent GDP growth as a measure of the average yearly constituency growth, this would imply that on average electing a criminally accused candidate would result 5.54 to 5.84 percent GDP growth per year (as compared to the 6 percent otherwise).

This suggests that the effects of criminal candidates are not just statistical important; rather, they are very clear economic costs to their elections. As we note early, while the methodology allows for the estimation of a clear causal relationship, the estimated impact are only valid near the discontinuity. That is, these are the losses associated with the election of criminally accused politicians in very close elections. Our results do not directly outside of the particular case. In part, the effects in elections which are not close depend on what sort of criminally accused politicians present themselves.

Some argue that parties have an incentive to present "criminals" in close elections insofar as they are able to suppress the vote and influence the outcome (Aidt et al. 2012). If this is true, it would suggest that our effects are an upper-bound. At the other extreme, it might be expected that are more likely to nominate candidates to seats which are relatively uncontested (Golden and Tiwari, 2009) which would suggest that our estimates are lower bounds.

Both of these arguments relate the propensity of criminals to run (and also their type) to the ex-ante perceived probability of election. Unfortunately, we are unable to observe the ex-ante perceptions-the data only show ex-post results. While these two can differ

\footnotetext{
${ }^{26}$ We cannot investigate the impact on alternate dependent variable since the elasticities are only available for the original dependent variable.
} 
dramatically over the entire sample, the ex-post results are likely relatively correlated with the ex-ante probabilities and therefore also with the ex-ante perceptions. We find that criminally accused candidates are more likely to be the winning candidate as the win margin increases. Moreover, the number of criminal accusations also increases with the win margin. While not conclusive, it does suggest that our results may be lower bound estimate for the overall average in the sample.

\section{Conclusions}

In this paper, we estimate the economic costs of electing criminally accused politicians by utilizing criminal accusations disclosure of candidates for Indian state legislatures for the state elections held between 2003 and 2008 in India. We use this unique data set to compare criminally accused candidates that barely won with criminally accused candidates that barely lost.

Our main finding suggests negative effect of electing criminally accused politicians on measures of economic activity at the constituency level in Indian states. The estimated effect is statistically significant and economically meaningful. In particular, we find that constituencies that elect criminally accused politicians experience $2.7 \%$ to $7.6 \%$ lower GDP growth per year in the Indian states.

Our results are particularly relevant for policy makers in many developed and developing countries who are grappling with similar situations. In particular, our results are well-timed with recent Supreme Court Judgement in India that bars lawmakers (elected representatives) convicted of serious crimes from serving in national and state legislatures, even if the conviction is being appealed. Also, on June 25th, 2014, the Indian Prime Minister gave directives to the federal law ministry to work out a mechanism to settle criminal and other court cases against politicians within a year, which was his commitment during the recently concluded elections. 
Although Vaishnav (2011) explores the conditions under which political parties select candidates with serious criminal records to contest elections in India, we present the first quantitative estimates of the economic costs of electing criminally accused politicians to state assemblies in India at the constituency level. Since there is no time series data of economic growth at the constituency level, we use the intensity of night lights in satellite imagery as a proxy for local economic growth. The size of the estimated negative effect of electing criminally accused politicians on measures of economic activity becomes larger when we consider candidates accused of serious crimes or financial crimes, thus reinforcing the political and economic relevance of the question!

Given the high economic costs of electing criminally accused politicians in India, it will be insightful to explore the various heterogeneities and mechanisms behind the estimated negative effects. We leave this for future work. 


\section{References}

Aidt, Toke, Miriam A. Golden, and Devesh Tiwari. "Criminality in the Indian National Legislature." Working Paper, 2012.

Aidt, Toke, Miriam Golden, and Devesh Tiwari. "Criminality and Incumbency of Candidates to the National Legislature in India1." Working Paper, 2010.

Albouy, David. "Partisan Representation in Congress and the Geographic Distribution of Federal Funds." 2009.

Ansolabehere, Stephen and James M Snyder. "Party Control of State Government and the Distribution of Public Expenditures." Scandinavian Journal of Economics, December 2006, 108 (4), pp. 547-569.

Association for Democratic Reform. "Analysis of Candidates Contesting in Uttar Pradesh Assembly Elections 2012." Press Release on February 24th, 2012.

Association for Democratic Reform. "Analysis of Criminal, Financial and other details of Newly Elected MLAs of the Uttar Pradesh Assembly Elections 2012." Press Release on March 11th, 2012.

Bardhan, Pranab. "Corruption and Development: A Review of Issues." Journal of Economic Literature, 1997, 35 (3), pp. 1320-1346.

Banerjee, Abhijit V., Selvan Kumar, Rohini Pande, and Felix Su. "Do Informed Voters Make Better Choices? Experimental Evidence from Urban India." Working Paper, 2011.

Banerjee, Abhijit V., Donald Green, Jeffrey McManus, and Rohini Pande. "Are Poor Voters Indifferent to Whether Elected Leaders are Criminal or Corrupt? A Vignette Experiment in Rural India." Working Paper, 2014. 
Bhalotra, Sonia, and Irma Clots-Figueras. "Health and the Political Agency of Women." American Economic Journal: Economic Policy, 2014, 6 (2), pp. 164-197.

Bhalotra, Sonia, Irma Clots-Figueras, Guilhem Cassan, and Lakshmi Iyer. "Religion, Politician Identity and Development Outcomes: Evidence from India." Journal of Economic Behavior \& Organization, 2014, 104, pp. 4-17.

Bhalotra, Sonia, Irma Clots-Figueras, and Lakshmi Iyer. "Path-Breakers: How Does Women's Political Participation Respond to Electoral Success?." IZA Discussion Paper No. 7771, 2013.

Baskaran, Thushyanthan, Brian Min, and Yogesh Uppal. "Election Cycles and Electricity Provision: Evidence from a Quasi-experiment with Indian Bye-elections." Working Paper, 2014.

Besley, Timothy and Robin Burgess. "Can Labor Regulation Hinder Economic Performance? Evidence from India." The Quarterly Journal of Economics, February 2004, 119 (1), pp. $91-134$.

Bickenbach, Frank, Eckhardt Bode, Mareike Lange, and Peter Nunnenkamp. "Night Lights and Regional GDP." Kiel Working Paper No. 1888, 2013.

Clots-Figuerasa, Irma. "Are Female Leaders Good for Education?." American Economic Journal: Applied Economics, 2012, 4 (1), pp. 212-244.

Chaudhury, Nazmul, Jeffrey Hammer, Michael Kremer, Karthik Muralidharan, and F. Halsey Rogers. "Missing in Action: Teacher and Health Worker Absence in Developing Countries." The Journal of Economic Perspectives, 2006, 20 (1), pp. 91-116.

Dreher, Axel and Thomas Herzfeld. "The Economic Costs of Corruption: A Survey and New Evidence." Public Economics, 2005, 506001. 
Elvidge, Christopher D., Kimberly E. Baugh, Eric A. Kihn, Herbert W. Kroehl, and Ethan R. Davis. "Mapping City Lights with Nighttime Data from the DMSP Operational Linescan System." Photogrammetric Engineering and Remote Sensing, 1997, 63 (6), pp. 727-734.

Elvidge, Christopher D. et al. "Night-time Lights of the World: 1994-1995." ISPRS Journal of Photogrammetry and Remote Sensing, 2001, 56 (2), pp. 81-99.

Faccio, Mara. "Politically Connected Firms." The American Economic Review, 2006, 96 (1), pp. 369-386.

Ferraz, Claudio, and Frederico Finan. "Exposing Corrupt Politicians: The Effects of Brazil's Publicly Released Audits on Electoral Outcomes." The Quarterly Journal of Economics, 2008, 123 (2), pp. 703-745.

Ferraz, Claudio, Frederico Finan, and Diana B. Moreira. "Corrupting Learning: Evidence from Missing Federal Education Funds in Brazil." Journal of Public Economics, 2012, 96 (9), pp. $712-726$.

Finan, Frederico S. "Political Patronage and Local Development : A Brazilian Case Study." 2004.

Fisman, Raymond. "Estimating the Value of Political Connections." The American Economic Review, February 2001, 91 (4), pp. 1095-1102.

Fisman, Raymond., Florian Schulz, and Vikrant Vig. "Private Returns to Public Office." forthcoming Journal of Political Economy, 2014.

Golden, Miriam A., and Devesh Tiwari. "Criminality and Malfeasance among National Legislators in Contemporary India." In APSA 2009 Annual Meeting Paper, 2009.

Gyimah-Brempong, Kwabena. "Corruption, Economic Growth, and Income Inequality in Africa." Economics of Governance, 2002, 3 (3), pp. 183-209. 
Henderson, J. Vernon, Adam Storeygard, and David N. Weil. "Measuring Economic Growth from Outer Space." The American Economic Review, 2012, 102 (2), pp. 994-1028.

Imbens, Guido, and Karthik Kalyanaraman "Optimal Bandwidth Choice for the Regression Discontinuity Estimator." The Review Of Economic Studies, 2012, 79 (3), pp. 933-959.

Jaffrelot, Christophe. "The Rise of the Other Backward Classes in the Hindi Belt." The Journal of Asian Studies, February, 2000, 59 (1), pp. 86-108.

Kaufmann, Daniel. "Rethinking Governance." World Bank Institute, World Bank, Washington, DC 2002.

Khwaja, Asim and Atif Mian. "Do Lenders Favor Politically Connected Firms? Rent Provision in an Emerging Market." The Quarterly Journal of Economics, 2005, 120 (4), pp. $1371-1411$.

Kohli, Atul and Prerna Singh. "Routledge Handbook of Indian Politics." 2013.

Lee, David S. "Randomized Experiments from Non-Random Selection in US House Elections." Journal of Econometrics, 2008, $142(2)$, pp. 675-697.

Lee, David and Thomas Lemieux. "Regression Discontinuity Designs in Economics." Journal of Economic Literature, 2010, 48 (June), pp. 281-355.

Mauro, Paolo. "Corruption and Growth." The Quarterly Journal of Economics., 1995, 110 (3), pp. 681-712.

McCrary, Justin. "Manipulation of the Running Variable in the Regression Discontinuity Design: A Density Test ." Journal of Econometrics., 2008, 142 (2), pp. 698-714.

Nagavarapu, Sriniketh, and Sheetal Sekhri. "Less Is More? Implications of Regulatory Capture for Natural Resource Depletion." Working Paper, 2014. 
Nichols, Austin. "rd 2.0: Revised Stata module for regression discontinuity estimation." http://ideas.repec.org/c/boc/bocode/s456888.html, 2011.

Niehaus, Paul and Sandip Sukhtankar. "Corruption Dynamics: The Golden Goose Effect." American Economic Journal: Economic Policy, 2013, 5 (4), pp. 230-269.

Olken, Benjamin A., and Rohini Pande. "Corruption in Developing Countries." Working Paper, 2012.

Olken, Benjamin A. "Corruption and the Costs of Redistribution: Micro Evidence from Indonesia." Journal of Public Economics, 2006, 90 (4), pp. 853-870.

Olken, Benjamin A. "Monitoring Corruption: Evidence from a Field Experiment in Indonesia." Journal of Political Economy, 2007, 115 (2), pp. 200-249

Reinikka, Ritva, and Jakob Svensson. "Local Capture: Evidence from a Central Government Transfer Program in Uganda." The Quarterly Journal of Economics, 2004, 119 (2), pp. 679-705.

Rose-Ackerman, Susan and Rory Truex. "Corruption and Policy Reform." Yale Law \& Economics Research Working Paper, 2012, 444, pp. 1-62.

Sam, Asher, and Paul Novosad. "Politics and Local Economic Growth: Evidence from India." Working Paper, 2013.

Shleifer, Andrei, and Robert W. Vishny. "Politicians and Firms." The Quarterly Journal of Economics, 1994, 109 (4), pp. 995-1025.

Storeygard, Adam. "Farther on Down the Road: Transport Costs, Trade and Urban Growth in Sub-Saharan Africa.", Working Paper, 2014.

Sukhtankar, Sandip. "Sweetening the Deal? Political Connections and Sugar Mills in India." American Economic Journal: Applied Economics, 2012, 4 (3), pp. 43-63. 
Uppal, Yogesh. "The Disadvantaged Incumbents: Estimating Incumbency Effects in Indian State Legislatures." Public Choice, 2009, 138 (1-2), pp. 9-27.

Vaishnav, Milan. "Caste Politics, Credibility and Criminality: Political Selection in India." Working Paper, South Asia Program, Carnegie Endowment for International Peace, 2011.

Vaishnav, Milan. "The Market for Criminality: Money, Muscle and Elections in India." Typescript, Department of Political Science, Columbia University, 2011a.

Vaishnav, Milan. "Doing Good by Doing Bad: Why Indian Voters Support Criminal Politicians." Typescript, Department of Political Science, Columbia University, 2011b.

Wade, Robert. "The Market for Public Office: Why the Indian State is not Better at Development." World Development, 1985, 13 (4), pp. 467-497. 
TABLE 1

Number of Constituencies and Election year

\begin{tabular}{|c|c|c|}
\hline State Name & Number of Constituencies & Election Years* \\
\hline Arunachal Pradesh & 60 & 1999, 2004, 2009 \\
\hline Assam & 126 & 2001, 2006, 2011 \\
\hline Bihar & 243 & 2000, 2005, 2010 \\
\hline Goa & 40 & 2002, 2007, 2012 \\
\hline Gujarat & 182 & 2002, 2007, 2012 \\
\hline Haryana & 90 & 2000, 2005, 2009 \\
\hline Himachal Pradesh & 68 & 2003, 2007, 2012 \\
\hline Jharkhand & 81 & $\mathbf{2 0 0 5}, 2009$ \\
\hline Kerala & 140 & 2001, 2006, 2011 \\
\hline Maharashtra & 288 & 1999, 2004, 2009 \\
\hline Manipur & 60 & 2002, 2007, 2012 \\
\hline Meghalaya & 60 & 2003, 2008, 2013 \\
\hline Nagaland & 60 & 2003, 2008, 2013 \\
\hline Orissa & 147 & 2000, 2004, 2009 \\
\hline Punjab & 117 & 2002, 2007, 2012 \\
\hline Tamil Nadu & 234 & 2001, 2006, 2011 \\
\hline Tripura & 60 & 2003, 2008, 2013 \\
\hline Uttar Pradesh & 403 & 2002, 2007, 2012 \\
\hline Uttarakhand & 70 & 2002, 2007, 2012 \\
\hline West Bengal & 294 & 2001, 2006, 2011 \\
\hline Total & 2823 & \\
\hline
\end{tabular}


TABLE 2

Descriptive Statistics

\begin{tabular}{|c|c|c|c|c|c|c|}
\hline & \multicolumn{3}{|c|}{ All Elections } & \multicolumn{3}{|c|}{ Elections Within Margin $<=5 \%$} \\
\hline & Criminal $=1$ & Criminal $=0$ & Difference & Criminal $=1$ & Criminal $=0$ & Difference \\
\hline & \multicolumn{6}{|c|}{ Panel A: Main Outcome Variable } \\
\hline Growth of Light & $\begin{array}{c}2.08 \\
{[75.11]}\end{array}$ & $\begin{array}{c}2.80 \\
{[98.14]}\end{array}$ & $\begin{array}{l}-0.72 \\
{[2.85]}\end{array}$ & $\begin{array}{c}-2.01 \\
{[83.29]}\end{array}$ & $\begin{array}{c}1.90 \\
{[87.8]}\end{array}$ & $\begin{array}{l}-3.92 \\
{[4.85]}\end{array}$ \\
\hline \multirow[t]{2}{*}{ Observations } & 1,967 & 1,726 & & 621 & 626 & \\
\hline & \multicolumn{6}{|c|}{ Panel B: Predetermined Variables } \\
\hline Growth of Light Previous Year & $\begin{array}{c}16.0 \\
{[75.5]}\end{array}$ & $\begin{array}{c}30.8 \\
{[140.3]}\end{array}$ & $\begin{array}{c}-14.9 \dagger \\
{[7.23]}\end{array}$ & $\begin{array}{c}27.9 \\
{[91.6]}\end{array}$ & $\begin{array}{c}35.4 \\
{[133.9]}\end{array}$ & $\begin{array}{l}-7.50 \\
{[12.9]}\end{array}$ \\
\hline Log Electorate Size Previous Election & $\begin{array}{l}12.0 \\
{[0.49]}\end{array}$ & $\begin{array}{l}12.1 \\
{[0.42]}\end{array}$ & $\begin{array}{l}-0.072 \dagger \\
{[0.030]}\end{array}$ & $\begin{array}{l}12.1 \\
{[0.43]}\end{array}$ & $\begin{array}{l}12.1 \\
{[0.38]}\end{array}$ & $\begin{array}{c}0.00076 \\
{[0.046]}\end{array}$ \\
\hline Log Number Voted Previous Election & $\begin{array}{c}11.5 \\
{[0.45]}\end{array}$ & $\begin{array}{c}11.6 \\
{[0.38]}\end{array}$ & $\begin{array}{l}-0.071 \ddagger \\
{[0.027]}\end{array}$ & $\begin{array}{c}11.6 \\
{[0.37]}\end{array}$ & $\begin{array}{c}11.6 \\
{[0.35]}\end{array}$ & $\begin{array}{c}-0.018 \\
{[0.041]}\end{array}$ \\
\hline Log Winner's Assets & $\begin{array}{c}14.9 \\
{[2.10]}\end{array}$ & $\begin{array}{c}14.9 \\
{[1.90]}\end{array}$ & $\begin{array}{c}-0.00015 \\
{[0.13]}\end{array}$ & $\begin{array}{c}14.8 \\
{[2.27]}\end{array}$ & $\begin{array}{c}15.0 \\
{[1.56]}\end{array}$ & $\begin{array}{c}-0.25 \\
{[0.22]}\end{array}$ \\
\hline Log Winner's Liability & $\begin{array}{c}7.46 \\
{[6.59]}\end{array}$ & $\begin{array}{c}6.87 \\
{[6.44]}\end{array}$ & $\begin{array}{c}0.59 \\
{[0.43]}\end{array}$ & $\begin{array}{c}8.27 \\
{[6.50]}\end{array}$ & $\begin{array}{c}7.33 \\
{[6.34]}\end{array}$ & $\begin{array}{c}0.94 \\
{[0.72]}\end{array}$ \\
\hline Log Runner-up's Assets & $\begin{array}{c}14.9 \\
{[2.11]}\end{array}$ & $\begin{array}{c}14.7 \\
{[2.15]}\end{array}$ & $\begin{array}{c}0.14 \\
{[0.14]}\end{array}$ & $\begin{array}{c}14.8 \\
{[2.30]}\end{array}$ & $\begin{array}{c}14.9 \\
{[1.77]}\end{array}$ & $\begin{array}{l}-0.14 \\
{[0.23]}\end{array}$ \\
\hline Log Runner-up's Liability & $\begin{array}{c}7.31 \\
{[6.43]}\end{array}$ & $\begin{array}{c}6.92 \\
{[6.42]}\end{array}$ & $\begin{array}{c}0.39 \\
{[0.42]}\end{array}$ & $\begin{array}{c}6.94 \\
{[6.56]}\end{array}$ & $\begin{array}{c}6.88 \\
{[6.48]}\end{array}$ & $\begin{array}{l}0.057 \\
{[0.73]}\end{array}$ \\
\hline Winner's Gender Previous Election & $\begin{array}{c}0.074 \\
{[0.26]}\end{array}$ & $\begin{array}{l}0.053 \\
{[0.22]}\end{array}$ & $\begin{array}{c}0.021 \\
{[0.016]}\end{array}$ & $\begin{array}{l}0.075 \\
{[0.26]}\end{array}$ & $\begin{array}{c}0.069 \\
{[0.25]}\end{array}$ & $\begin{array}{c}0.0063 \\
{[0.029]}\end{array}$ \\
\hline Runner-up's Gender Previous Election & $\begin{array}{l}0.070 \\
{[0.25]}\end{array}$ & $\begin{array}{c}0.048 \\
{[0.21]}\end{array}$ & $\begin{array}{c}0.022 \\
{[0.015]}\end{array}$ & $\begin{array}{l}0.057 \\
{[0.23]}\end{array}$ & $\begin{array}{l}0.044 \\
{[0.21]}\end{array}$ & $\begin{array}{c}0.013 \\
{[0.025]}\end{array}$ \\
\hline Runner-up's Education & $\begin{array}{c}2.35 \\
{[1.25]}\end{array}$ & $\begin{array}{c}2.21 \\
{[1.20]}\end{array}$ & $\begin{array}{c}0.14^{*} \\
{[0.080]}\end{array}$ & $\begin{array}{c}2.44 \\
{[1.23]}\end{array}$ & $\begin{array}{c}2.26 \\
{[1.19]}\end{array}$ & $\begin{array}{c}0.18 \\
{[0.14]}\end{array}$ \\
\hline Winner's Education & $\begin{array}{c}2.22 \\
{[1.19]}\end{array}$ & $\begin{array}{c}2.48 \\
{[1.15]}\end{array}$ & $\begin{array}{l}-0.26 \$ \\
{[0.077]}\end{array}$ & $\begin{array}{c}2.36 \\
{[1.15]}\end{array}$ & $\begin{array}{c}2.37 \\
{[1.21]}\end{array}$ & $\begin{array}{c}-0.0063 \\
{[0.13]}\end{array}$ \\
\hline SC Reserved & $\begin{array}{c}0.11 \\
{[0.31]}\end{array}$ & $\begin{array}{c}0.13 \\
{[0.34]}\end{array}$ & $\begin{array}{c}-0.025 \\
{[0.021]}\end{array}$ & $\begin{array}{c}0.11 \\
{[0.31]}\end{array}$ & $\begin{array}{l}0.075 \\
{[0.26]}\end{array}$ & $\begin{array}{c}0.031 \\
{[0.032]}\end{array}$ \\
\hline ST Reserved & $\begin{array}{l}0.050 \\
{[0.22]}\end{array}$ & $\begin{array}{l}0.053 \\
{[0.22]}\end{array}$ & $\begin{array}{l}-0.0028 \\
{[0.014]}\end{array}$ & $\begin{array}{l}0.031 \\
{[0.18]}\end{array}$ & $\begin{array}{l}0.025 \\
{[0.16]}\end{array}$ & $\begin{array}{l}0.0063 \\
{[0.019]}\end{array}$ \\
\hline Ruling Party Previous Election & $\begin{array}{c}0.52 \\
{[0.50]}\end{array}$ & $\begin{array}{c}0.57 \\
{[0.50]}\end{array}$ & $\begin{array}{c}-0.048 \\
{[0.033]}\end{array}$ & $\begin{array}{c}0.47 \\
{[0.50]}\end{array}$ & $\begin{array}{c}0.50 \\
{[0.50]}\end{array}$ & $\begin{array}{c}-0.031 \\
{[0.056]}\end{array}$ \\
\hline Observations & 503 & 438 & & 159 & 159 & \\
\hline
\end{tabular}


TABLE 3

Effect of Electing Criminally Accused Politicians on the Growth of Night Lights

\begin{tabular}{|c|c|c|}
\hline & $(1)$ & $(2)$ \\
\hline Dependent Variable: & \multicolumn{2}{|c|}{ Growth of Light } \\
\hline \multicolumn{3}{|l|}{ Panel A: Baseline } \\
\hline \multirow[t]{2}{*}{ Criminal } & $-26.67 * * *$ & $-17.31 * *$ \\
\hline & [9.33] & {$[7.27]$} \\
\hline \multirow{2}{*}{$\begin{array}{l}\text { State and Year Fixed Effects } \\
\text { R-squared }\end{array}$} & No & No \\
\hline & & 0.01 \\
\hline \multicolumn{3}{|c|}{ Panel B: State and Year Fixed Effects } \\
\hline \multirow{2}{*}{ Criminal } & $-25.21 * * *$ & $-16.41 * *$ \\
\hline & {$[8.46]$} & {$[6.58]$} \\
\hline \multirow{2}{*}{$\begin{array}{l}\text { State and Year Fixed Effects } \\
\text { R-squared }\end{array}$} & Yes & Yes \\
\hline & & 0.13 \\
\hline \multirow{2}{*}{$\begin{array}{l}\text { Method } \\
\text { Observations }\end{array}$} & Local Linear Regression & Parametric \\
\hline & 3,693 & 3,693 \\
\hline \multicolumn{3}{|c|}{$\begin{array}{l}\text { The dependent variable is Growth of Light. Criminal is a dummy variable that is } 1 \text { if a criminally accused candidate wins against a non-accused candidate } \\
\text { and } 0 \text { if criminally accused candidate loses against a non-accused candidate. The RD estimates in column (1) are based on a local linear regression using a } \\
\text { rectangular kernel and an optimal bandwidth calculator as suggested in Imbens-Kalyanaraman's (2012). The RD estimates in column (2) are based on a } \\
\text { fourth-order polynomial in margin of victory and the interaction of the polynomial terms with the criminal dummy. In Panel B, we account for state and year } \\
\text { fixed effects. In column (1), we do so by firstr tegressing Growth of Light on state and year dummies and then using the residuals from this regression as the } \\
\text { dependent variable. In column (2), we include state and year dummies in the regression equation. Standard errors are clustered at the constituency level and } \\
\text { given in parentheses. }\end{array}$} \\
\hline \multicolumn{3}{|c|}{ The values with $*, * *$, and $* * *$ indicate significance at the $10 \%, 5 \%$, and $1 \%$ levels, respectively. } \\
\hline
\end{tabular}


TABLE 4

Heterogeneous Effects of Criminally Accused: Local Linear Regression

\begin{tabular}{|c|c|c|c|c|c|}
\hline & $(1)$ & $(2)$ & (3) & (4) & $(5)$ \\
\hline Dependent Variable: & \multicolumn{5}{|c|}{ Growth of Light } \\
\hline \multicolumn{6}{|l|}{$\begin{array}{l}\text { Panel A: Local Linear } \\
\text { Regression }\end{array}$} \\
\hline Criminal & $\begin{array}{l}-53.28 * * * \\
{[280.52]}\end{array}$ & $\begin{array}{l}-3.30 \\
{[3.92]}\end{array}$ & $\begin{array}{l}-30.57 * * * \\
{[11.01]}\end{array}$ & $\begin{array}{l}-4.78 \\
{[23.21]}\end{array}$ & $\begin{array}{l}-28.95 \\
{[27.10]}\end{array}$ \\
\hline State and Year Fixed Effects & No & No & No & No & No \\
\hline \multicolumn{6}{|l|}{$\begin{array}{l}\text { Panel B: Local Linear } \\
\text { Regression Using Residuals }\end{array}$} \\
\hline Criminal & $\begin{array}{l}-56.50 * * * \\
{[19.04]}\end{array}$ & $\begin{array}{l}-3.85 \\
{[3.69]}\end{array}$ & $\begin{array}{l}-29.52 * * * \\
{[9.92]}\end{array}$ & $\begin{array}{l}2.16 \\
{[21.32]}\end{array}$ & $\begin{array}{l}-11.73 \\
{[23.47]}\end{array}$ \\
\hline State and Year Fixed Effects & Yes & Yes & Yes & Yes & Yes \\
\hline Sample & $\begin{array}{l}\text { BIMAROU } \\
\text { States }\end{array}$ & $\begin{array}{l}\text { Non- } \\
\text { BIMAROU } \\
\text { States }\end{array}$ & $\begin{array}{l}\text { Non-reserved } \\
\text { Constituencies }\end{array}$ & $\begin{array}{l}\text { SC } \\
\text { Constituencies }\end{array}$ & $\begin{array}{l}\text { ST } \\
\text { Constituencies }\end{array}$ \\
\hline Observations & 1,309 & 2,384 & 3,065 & 441 & 183 \\
\hline
\end{tabular}

The RD estimates above are based on a local linear regression using a rectangular kernel and an optimal bandwidth calculator as suggested in ImbensKalyanaraman's (2012). The dependent variable is Growth of Light. In Panel B, we account for state and year fixed effects by first regressing Growth of Light on state and year dummies and then using the residuals from this regression as the dependent variable. In column (1), the sample consists of BIMAROU states, which in our data is Bihar, Chhattisgarh, Jharkhand, Orissa, Uttar Pradesh and Uttarakhand. In column (2) we consider non-BIMAROU states. Columns (3), (4) and (5) restrict the sample to General constituencies, constituencies reserved for the Scheduled Caste (SC) candidates, and constituencies reserved for the Scheduled Tribes (ST) candidates respectively. Standard errors are clustered at the constituency level and given in

The values with ${ }^{*}{ }^{* *}$, and $* * *$ indicate significance at the $10 \%, 5 \%$, and $1 \%$ levels, respectively. 
TABLE 5

Alternate Definitions of Criminally Accused: Local Linear Regression

\begin{tabular}{|c|c|c|c|c|c|c|}
\hline & (1) & (2) & (3) & (4) & $(5)$ & (6) \\
\hline Dependent Variable: & \multicolumn{6}{|c|}{ Growth of Light } \\
\hline \multicolumn{7}{|c|}{ Panel A: Local Linear Regression } \\
\hline \multirow[t]{2}{*}{ Criminal } & $-24.23 * *$ & -15.43 & $-38.06 * *$ & -11.73 & $-34.17 * * *$ & $-48.84 * *$ \\
\hline & [11.66] & {$[10.10]$} & {$[16.58]$} & {$[8.71]$} & {$[10.84]$} & {$[21.86]$} \\
\hline State and Year Fixed Effects & No & No & No & No & No & No \\
\hline \multicolumn{7}{|c|}{ Panel B: Local Linear Regression Using } \\
\hline \multirow{2}{*}{ Criminal } & $-25.22 * *$ & -13.04 & $-40.93 * * *$ & -8.42 & $-36.59 * * *$ & $-48.86 * *$ \\
\hline & {$[10.97]$} & [8.93] & {$[14.44]$} & [7.77] & {$[10.41]$} & [19.98] \\
\hline State and Year Fixed Effects & Yes & Yes & Yes & Yes & Yes & Yes \\
\hline Sample & Serious & Non-serious & Financial & $\begin{array}{c}\text { Non- } \\
\text { Financial }\end{array}$ & $\begin{array}{l}\text { Multiple } \\
(>=2)\end{array}$ & $\underset{(>=5)}{\text { Multiple }}$ \\
\hline Observations & 1,623 & 2,070 & 1,255 & 2,438 & 2,312 & 732 \\
\hline
\end{tabular}

The RD estimates above are based on a local linear regression using a rectangular kernel and an optimal bandwidth calculator as suggested in Imbens-Kalyanaraman's (2012). The dependent variable is Growth of Light. In Panel B, we account for state and year fixed effects by first regressing Growth of Light on state and year dummies and then using the residuals from this regression as the dependent variable. In column (1), Criminal is 1 for a winner who had a serious criminal case against him and who ran against a non-criminal loser and 0 for a loser who had serious criminal accusation against him and ran against a non-criminal winner. In column (2), Criminal is 1 for a winner who had a non-serious criminal case against him and who ran against a loser who did not have any accusation and 0 for a loser who had a non-serious criminal accusation against him and ran against a winner who did not have any accusation agains him. In column (3), Criminal is 1 for a winner who was involved in a financial crime and ran against a non-criminal loser and 0 for a loser who was involved in a financial crime and ran against a non-criminal winner. In column (4), Criminal is 1 for a winner who was involved in a non-financial crime and ran against a non-criminal loser and 0 for a loser who was involved

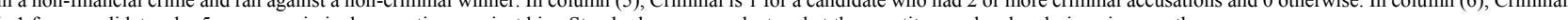

The values with $*, * *$, and $* * *$ indicate significance at the $10 \%, 5 \%$, and $1 \%$ levels, respectively. 
TABLE 6

Effect of Electing Criminally Accused Politicians on the Growth of Night Lights: Sample Averages

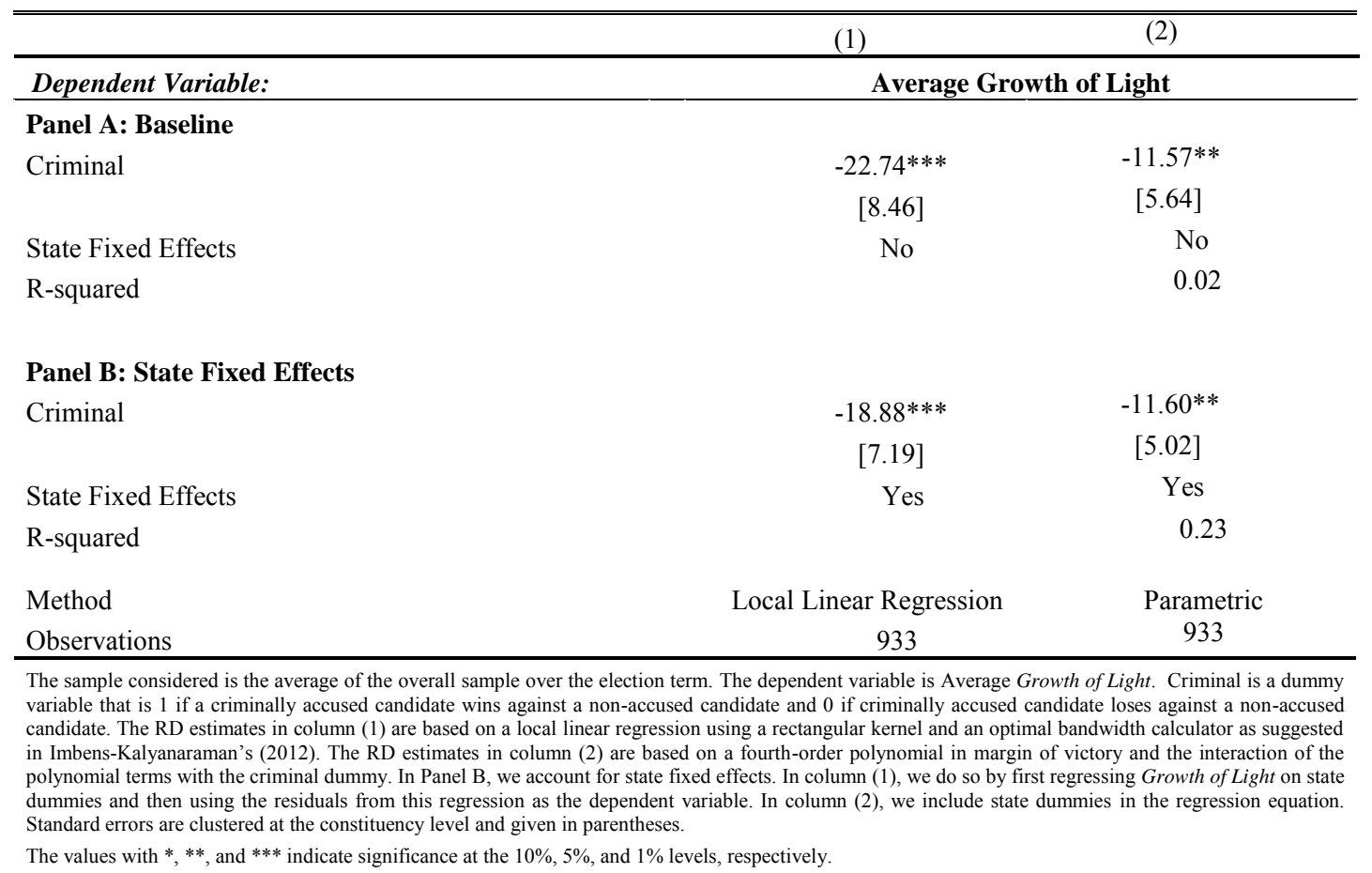


TABLE 7

Alternate Definitions of Criminally Accused: Parametric Fit

\begin{tabular}{|c|c|c|c|c|c|c|}
\hline & (1) & (2) & (3) & (4) & (5) & (6) \\
\hline Dependent Variable: & \multicolumn{6}{|c|}{ Growth of Light } \\
\hline \multicolumn{7}{|l|}{ Panel A: Parametric Fit } \\
\hline \multirow[t]{2}{*}{ Criminal } & -16.81 & $-19.10^{*}$ & $-33.56 * *$ & -12.49 & $-25.26 * * *$ & $-51.88 * *$ \\
\hline & {$[11.30]$} & {$[9.75]$} & {$[15.82]$} & {$[7.85]$} & {$[8.97]$} & {$[23.81]$} \\
\hline State and Year Fixed Effects & No & No & No & No & No & No \\
\hline R-squared & 0.01 & 0.01 & 0.01 & 0.01 & 0.01 & 0.01 \\
\hline \multicolumn{7}{|c|}{ Panel B: Parametric Fit with Fixed Effects } \\
\hline \multirow[t]{2}{*}{ Criminal } & $-18.17 *$ & $-17.39 *$ & $-37.87 * *$ & -10.68 & $-25.62 * * *$ & $-50.53 * *$ \\
\hline & {$[10.52]$} & {$[8.55]$} & {$[15.49]$} & {$[7.48]$} & {$[8.28]$} & {$[22.68]$} \\
\hline R-squared & 0.10 & 0.22 & 0.11 & 0.15 & 0.12 & 0.11 \\
\hline State and Year Fixed Effects & Yes & Yes & Yes & Yes & Yes & Yes \\
\hline Sample & Serious & Non-serious & Financial & $\begin{array}{c}\text { Non- } \\
\text { Financial }\end{array}$ & $\begin{array}{l}\text { Multiple } \\
(>=2)\end{array}$ & $\begin{array}{l}\text { Multiple } \\
(>=5)\end{array}$ \\
\hline Observations & 1,623 & 2,070 & 1,255 & 2,438 & 2.312 & 732 \\
\hline \multicolumn{7}{|c|}{ 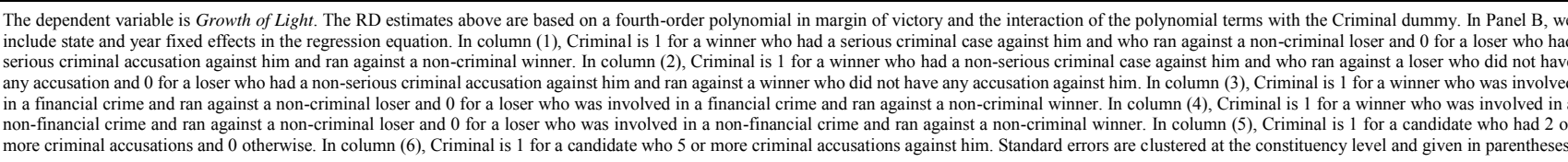 } \\
\hline
\end{tabular}


TABLE 8

Effect of Electing Criminally Accused Politicians on Constituency GDP Growth (in \%)

\begin{tabular}{lcccccc}
\hline \hline & (1) & (2) & (3) & (4) & (5) \\
\hline \hline & Base & Serious & Financial & Multiple (>=2) & Multiple (>=5) \\
\hline Coefficient & -25.2 & -42.1 & -76.4 & -47.7 & -60.1
\end{tabular}

Estimated Effect on GDP Growth (in \%)

\begin{tabular}{|c|c|c|c|c|}
\hline-7.6 & -12.6 & -22.9 & -14.3 & -18.0 \\
\hline-2.7 & -4.5 & -8.2 & -5.1 & -6.4 \\
\hline
\end{tabular}

The definition of the main explanatory variable changes across the columns: criminally accused. In column (1), in the base it takes a value of 1 for any candidate with at least one ongoing criminal accusation and 0 otherwise. In column (2), we consider only serious as defined by the Association for column (5), we consider criminally accused who had 5 or more cases against them. The upper-bound uses an elasticity of 0.3 . The lower-bound uses an elasticity of 0.107 
TABLE 9

Heterogeneous Effects of Criminally Accused: Parametric Fit

\begin{tabular}{|c|c|c|c|c|c|}
\hline & $(1)$ & $(2)$ & (3) & (4) & $(5)$ \\
\hline Dependent Variable: & \multicolumn{5}{|c|}{ Growth of Light } \\
\hline \multicolumn{6}{|l|}{ Panel A: Parametric Fit } \\
\hline Criminal & $\begin{array}{l}-40.69 * * \\
{[16.46]}\end{array}$ & $\begin{array}{l}-4.32 \\
{[4.04]}\end{array}$ & $\begin{array}{l}-17.74 * * \\
{[7.96]}\end{array}$ & $\begin{array}{l}-3.30 \\
{[29.28]}\end{array}$ & $\begin{array}{l}-43.39 \\
{[28.87]}\end{array}$ \\
\hline State and Year Fixed Effects & No & No & No & No & No \\
\hline R-squared & 0.01 & 0.01 & 0.01 & 0.01 & 0.03 \\
\hline \multicolumn{6}{|l|}{$\begin{array}{l}\text { Panel B: Parametric Fit with } \\
\text { Fixed Effects }\end{array}$} \\
\hline Criminal & $\begin{array}{l}-42.37 * * * \\
{[15.01]}\end{array}$ & $\begin{array}{l}-4.48 \\
{[3.99]}\end{array}$ & $\begin{array}{l}-17.04 * * \\
{[7.08]}\end{array}$ & $\begin{array}{l}-2.97 \\
{[31.41]}\end{array}$ & $\begin{array}{l}-39.65 \\
{[26.26]}\end{array}$ \\
\hline State and Year Fixed Effects & Yes & Yes & Yes & Yes & Yes \\
\hline R-squared & 0.14 & 0.35 & 0.12 & 0.18 & 0.58 \\
\hline Sample & $\begin{array}{l}\text { BIMAROU } \\
\text { States }\end{array}$ & $\begin{array}{l}\text { Non- } \\
\text { BIMAROU } \\
\text { States }\end{array}$ & $\begin{array}{l}\text { Non-reserved } \\
\text { Constituencies }\end{array}$ & $\begin{array}{l}\text { SC } \\
\text { Constituencies }\end{array}$ & $\begin{array}{l}\text { ST } \\
\text { Constituencies }\end{array}$ \\
\hline Observations & 1,309 & 2,384 & 3,065 & 441 & 183 \\
\hline $\begin{array}{l}\text { The dependent variable is Growth } \\
\text { the polynomial terms with the Crim } \\
\text { consists of BIMAROU states, whic } \\
\text { non-BIMAROU states. Columns } \\
\text { candidates, and constituencies reser } \\
\text { given in parentheses. } \\
\text { The values with } *, * * \text {, and } * * * \text { indi }\end{array}$ & $\begin{array}{l}\text { The RD estin } \\
\text { amy. In Panel } \\
\text { data is Bihar } \\
\text { nd (5) restrict } \\
\text { the Scheduled } \\
\text { ifficance at th }\end{array}$ & $\begin{array}{l}\text { above are based } \\
\text { e include state ar } \\
\text { hattisgarh, Jharkh } \\
\text { sample to Gener } \\
\text { es (ST) candidate } \\
6 \% \text {, and } 1 \% \text { le }\end{array}$ & $\begin{array}{l}\text { a fourth-order polyn } \\
\text { ear fixed effects in tl } \\
\text { l, Orissa, Uttar Prad } \\
\text { onstituencies, const } \\
\text { spectively. Standard } \\
\text {, respectively. }\end{array}$ & $\begin{array}{l}\text { ial in margin of vict } \\
\text { egression equation. } \\
\text { and Uttarakhand. In } \\
\text { ncies reserved for t } \\
\text { ors are clustered at t }\end{array}$ & $\begin{array}{l}\text { and the interactio } \\
\text { olumn (1), the san } \\
\text { lumn (2) we cons } \\
\text { Scheduled Caste ( } \\
\text { constituency level }\end{array}$ \\
\hline
\end{tabular}


Figure 1

Nighttime Light Output in India

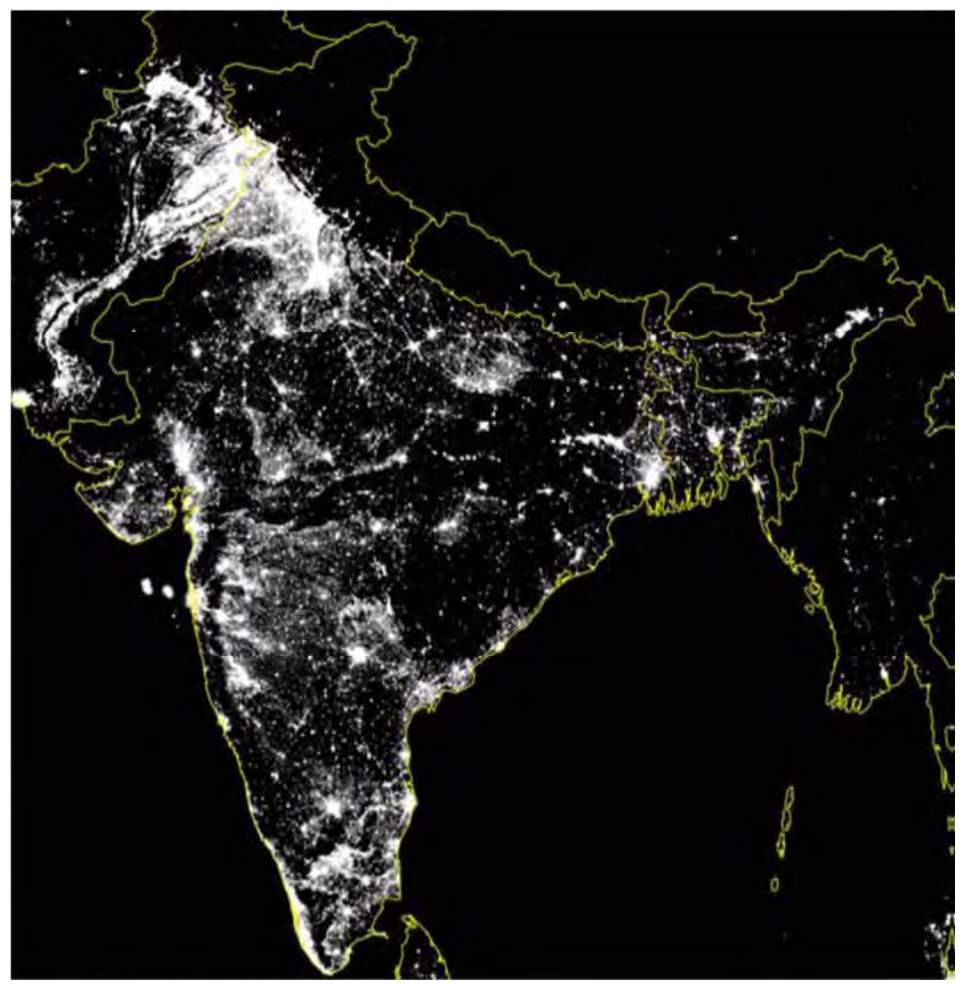

(a) 1992

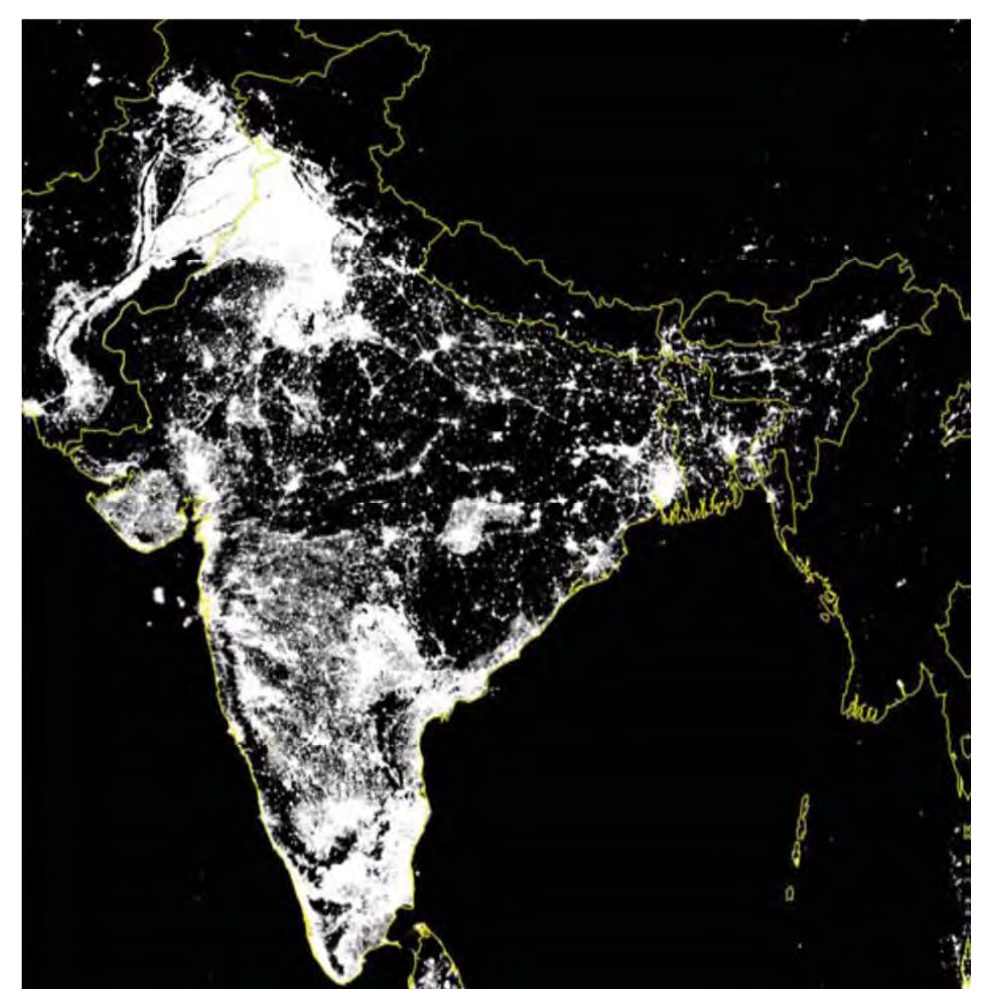

(b) 2009 
Figure 2

Effect of Criminal MLAs: All Criminals

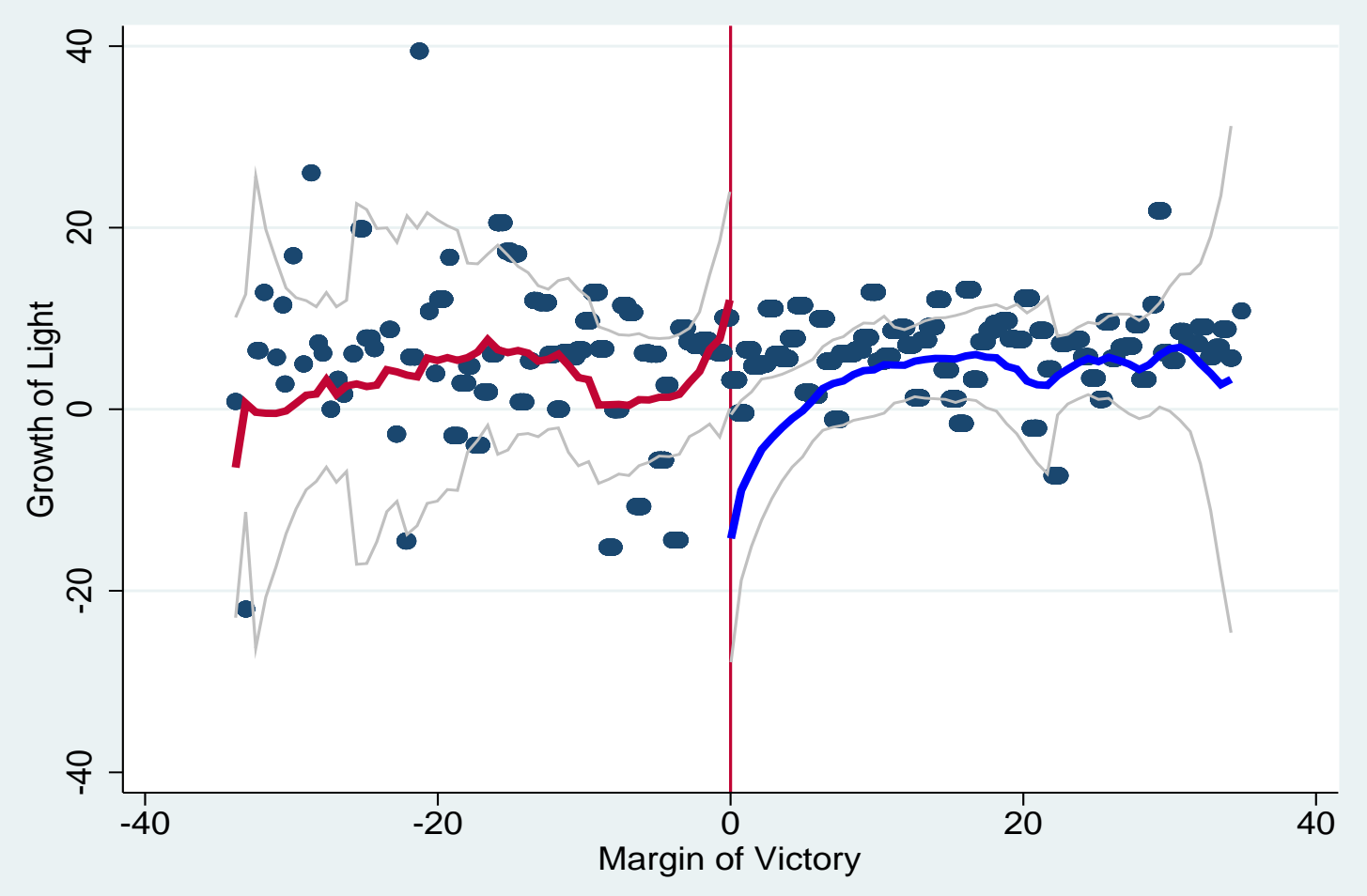

(a) Growth of Light

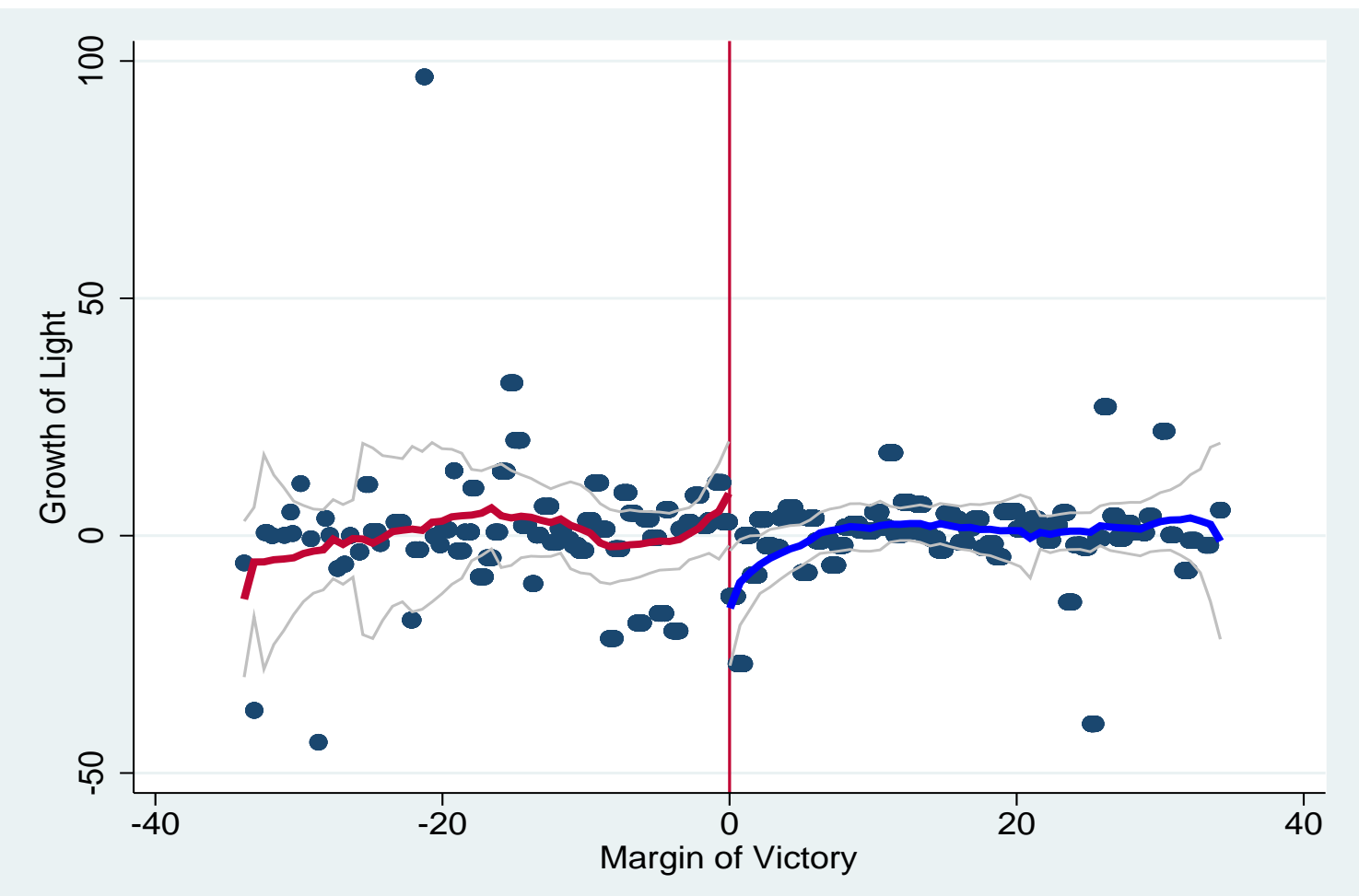

(b) Growth of Light: Residuals 
Figure 3

Predetermined Characteristics: Continuity Checks

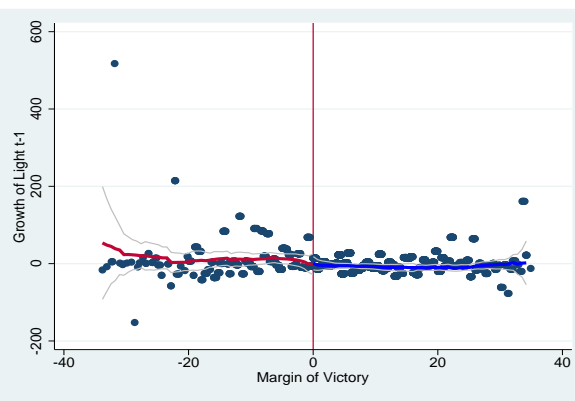

(a) Growth of Light t-1

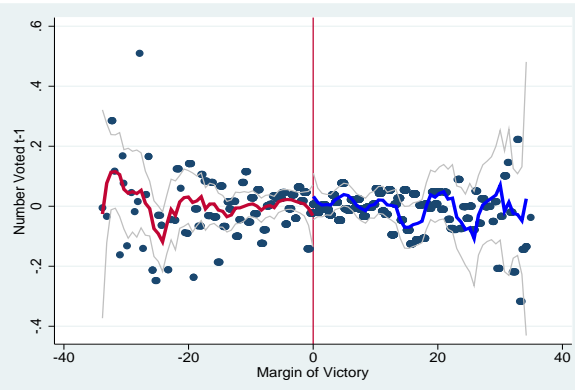

(c) Number Voted t-1

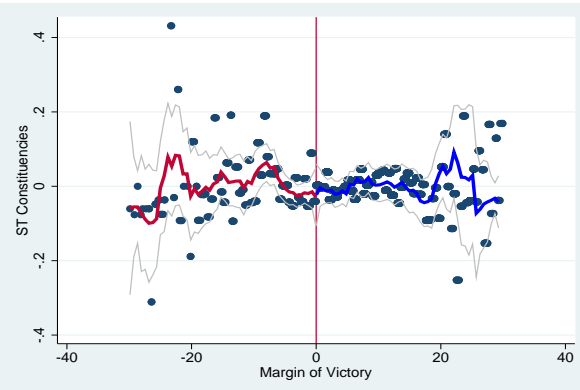

(e) ST Constituencies

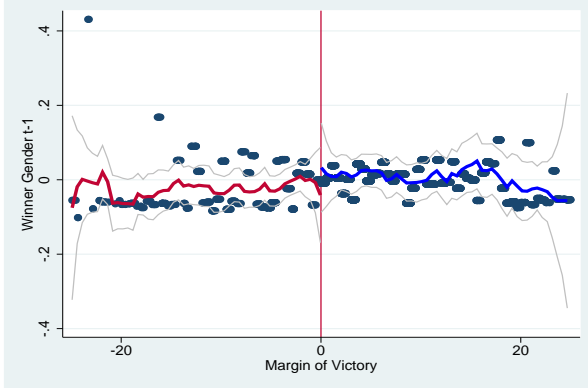

(g) Winner Gender t-1

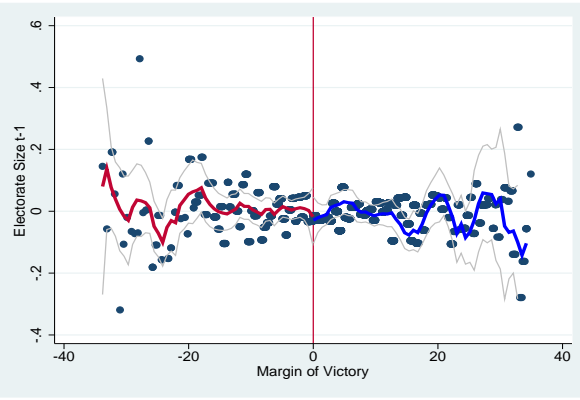

(b) Electorate Size t-1

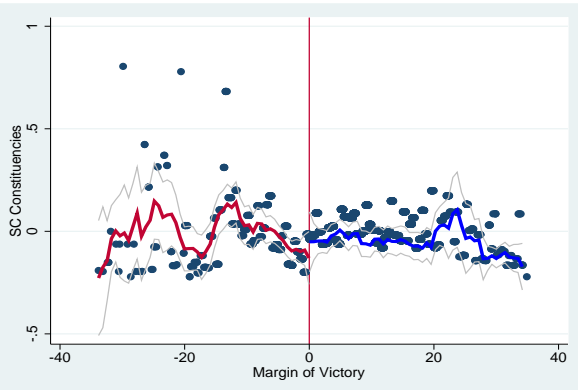

(d) SC Constituencies

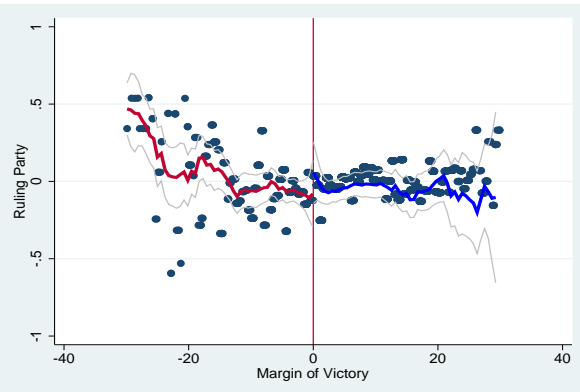

(f) Ruling Party t-1

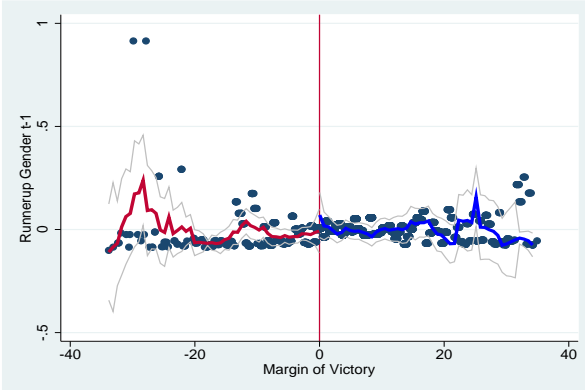

(h) Runner-up Gender t-1 
Figure 3

Predetermined Characteristics: Continuity Checks (contd)

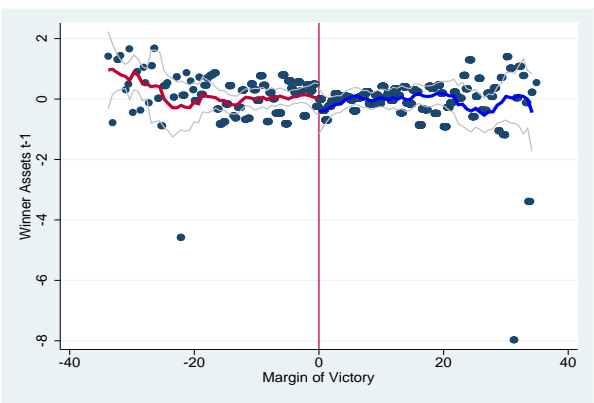

(i) Winner Assets t-1

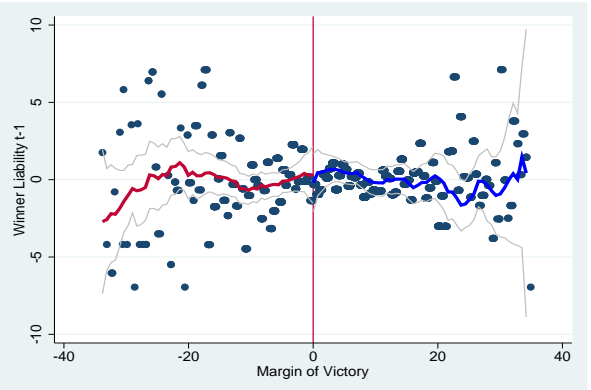

(k) Winner Liabilities t-1

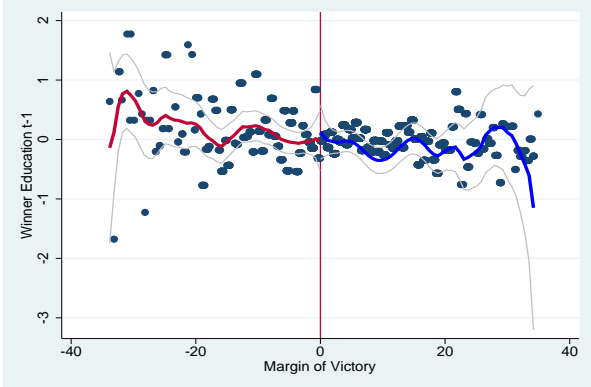

(m) Winner Education t-1

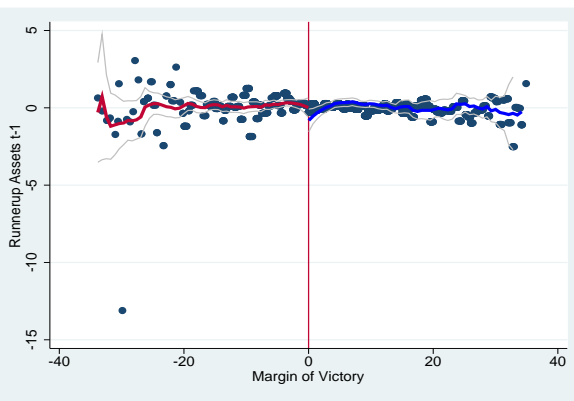

(j) Runner-up Assets t-1

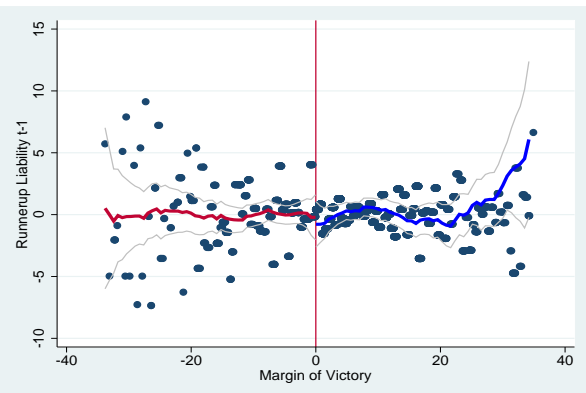

(1) Runner-up Liabilities t-1

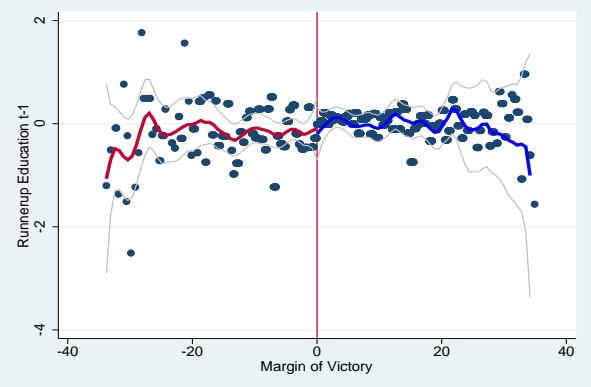

(n) Runner-up Education t-1 
Figure 4

Density Test of Running Variable: Margin of Victory

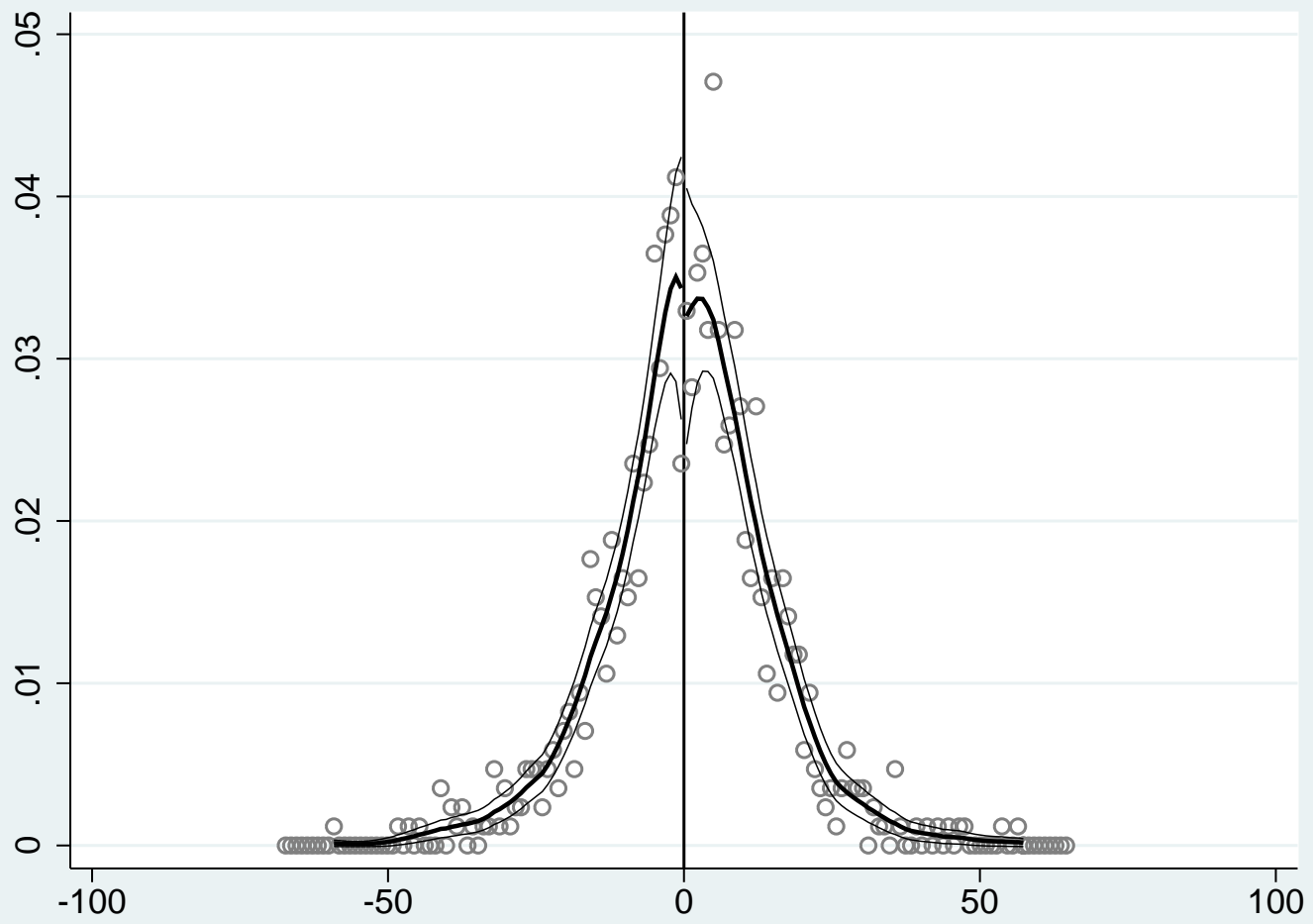




\section{APPENDIX}

A Affidavit by Candidate 


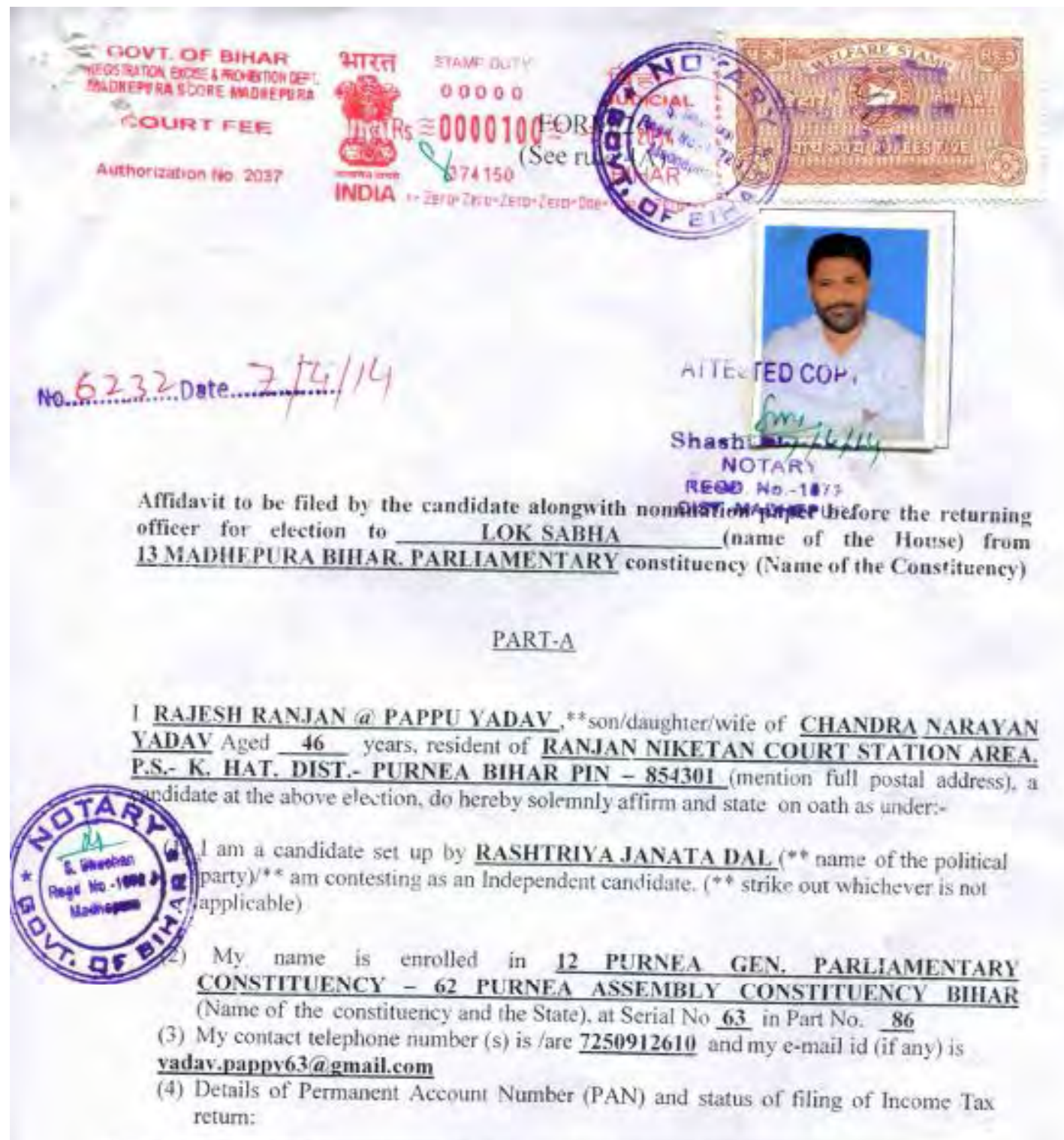

\begin{tabular}{|c|c|c|c|c|}
\hline $\begin{array}{l}\text { Sl. } \\
\text { No. }\end{array}$ & Names & PAN & $\begin{array}{l}\text { The financial year } \\
\text { for which the last } \\
\text { Income-tax retum } \\
\text { has been filed }\end{array}$ & $\begin{array}{l}\text { Total income } \\
\text { shown in Income- } \\
\text { tax return (in } \\
\text { Rupees) }\end{array}$ \\
\hline 1. & Self & AENPR3822G & $2012-13$ & $292530 /$ \\
\hline 2. & Spouse & AHCPK9167F & $2012-13$ & $659640 /-$ \\
\hline 3. & Dependent-1 & BSBPR9383M & NIL & NIL \\
\hline 4. & Dependent -2 & NIL & NIL & NIL \\
\hline 5. & Dependent-3. & NIL & NIL & NIL. \\
\hline
\end{tabular}


(5) I am /am not accused of any offences) punishable with imprisonment for two years or mone in a pending case(s) in which a charge (s) hashave been framed by the court(s) of competent jurisdiction.

If the deponent is accused of any such offence(s) he shall firnish the following information-

(i) The following case(s) is /are pending against me in which charges hate heen framed by the court for an offence punishable with imprisomment for two vears or more :-

(a) Case/First Information Report No.
Nos. together with complete
ATTACHED AS ANNEXURE - 1

details of concerned Police

(b) Section(s) ef the concerned Act(s) and shert deseription of the offence(s) for which charged

(c) Name of the Court, Case No, and date of order taking cognizance:

(d) Court(s) which framed the charge(s)

(e) Daie(s) on which the charge(s) was/were framed

ce

(f) Whether all or any of the proceedings(s) have been stayed by any Court(s) of competent

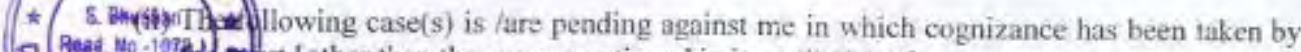

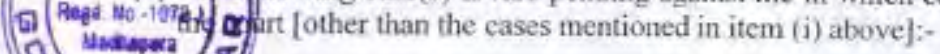

OFt B Bame of the Court, Case No. and date of order taking cognizance:

(b) The details of cases where the court has taken cognizance, section(s) of the Act(s) and description of the offerice(s) for which cognizance taken

(c) Details Appeal(s)/Application(s)

ATTACHED AS ANNEXURE - 1

ATTACHED AS ANNEXURE - 1 revision (if any) filed against the above order(s) ATTACHED AS ANNEXURE - 2

ATTACHED AS ANNEXURE - 2

(6) I have been/have not been convicted, of an offence(s) lother than any offence (s) referred to in sub-section (I) or sub-section (2), or covered in sub-section (3), of section 8 of the Representation of the People Act, 1951 (43 of 1951)] and sentenced to imprisonment for one year or more.

If the deponent is convicged and punished as aforesaid, hengll furnish the following information:
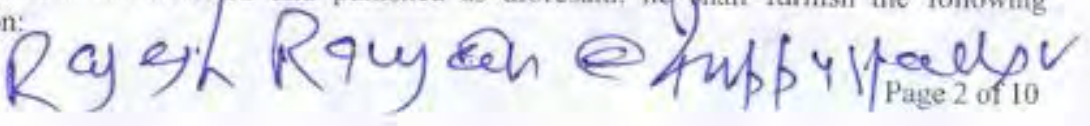
In the following case, I have been convicted and sentenced to imprisonment by a court of law:

\begin{tabular}{|c|c|c|}
\hline (a) & $\begin{array}{l}\text { The Details of cases, section(s) of } \\
\text { the concerned Act(s) and } \\
\text { description of the offence(s) for } \\
\text { which convicted }\end{array}$ & $\begin{array}{l}\text { K. Hat. P.S Case No. } 230 / 98 \text { U/s } 302,34,120 \\
\text { (B), } 307 / 34 \text { IPC \& } 27 \text { Arms Act. In connection } \\
\text { with murder of Ajit Sarkar F.x. ML.A. Purnea. }\end{array}$ \\
\hline (b) & $\begin{array}{l}\text { Name of the Court, Case No. and } \\
\text { date of onder(s): }\end{array}$ & $\begin{array}{r}\text { AD.I. XI. P } \\
\mathrm{Jt}\end{array}$ \\
\hline (c) & Punishment imposed & \\
\hline (d) & $\begin{array}{l}\text { Whether any appeal was/has been } \\
\text { filed against the conviction order. } \\
\text { If so, details and the present status } \\
\text { of the appeal. }\end{array}$ & $\begin{array}{l}\text { Yes. } \\
\begin{array}{l}\text { Cr. Appeal No. } 418 / 2008 \text { was filed before the } \\
\text { Hon'ble High Cenrt. } \\
\text { Appeal has beren allowed and the petitioner has been } \\
\text { acquitied by order dt. 17-05-2013. }\end{array}\end{array}$ \\
\hline
\end{tabular}

(7) That I give herein below the details of the assets (movable and immovable ete, ) of nyself. thy spouse and all dependents:

\section{A. Details of movable assets:}

Note: 1. Assets in joint name indicating the extent of joint ovnership will also have to be

\footnotetext{
given. of of depositimvestment, the details including Serial Number, Anount, date of deposit, the scheme, Name of the Bank/Institution and Branch are to be given

3. Value of Bonds/Share Debentures as per current market value in Stock exchange in respect of listed companies and as per books in case of non-listed companies should be given.

4. Dependent here has the same meaning as assigned in Explanation (v) under section 75A of the Representation of the People Act. 1951.

Note: 5 . Details ircluding amount is to be given separately in respect of each investment.
}

\begin{tabular}{|c|c|c|c|c|c|c|}
\hline $\begin{array}{l}\text { SI. } \\
\text { No. }\end{array}$ & Description & Self & Spouse & Dependent-1 & Dependent-2 & Dependent-3 \\
\hline (i) & Cash in hand & $22000 /-$ & $100000 /-$ & NIL & NIL & NIL \\
\hline (ii) & $\begin{array}{l}\text { Details of deposit in } \\
\text { Bank accounts(FDRs, } \\
\text { Term Deposits and all } \\
\text { other types of deposits } \\
\text { including saving } \\
\text { accounts), Deposits with } \\
\text { Financial Institutions, } \\
\text { Non-Banking Financial } \\
\text { Companies and } \\
\text { Cooperative societies and } \\
\text { the amount in each such } \\
\text { deposit }\end{array}$ & 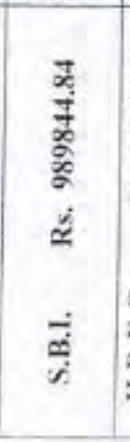 & 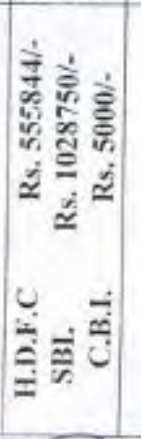 & $30,000 /-$ & $30,000 /-$ & NIL \\
\hline
\end{tabular}




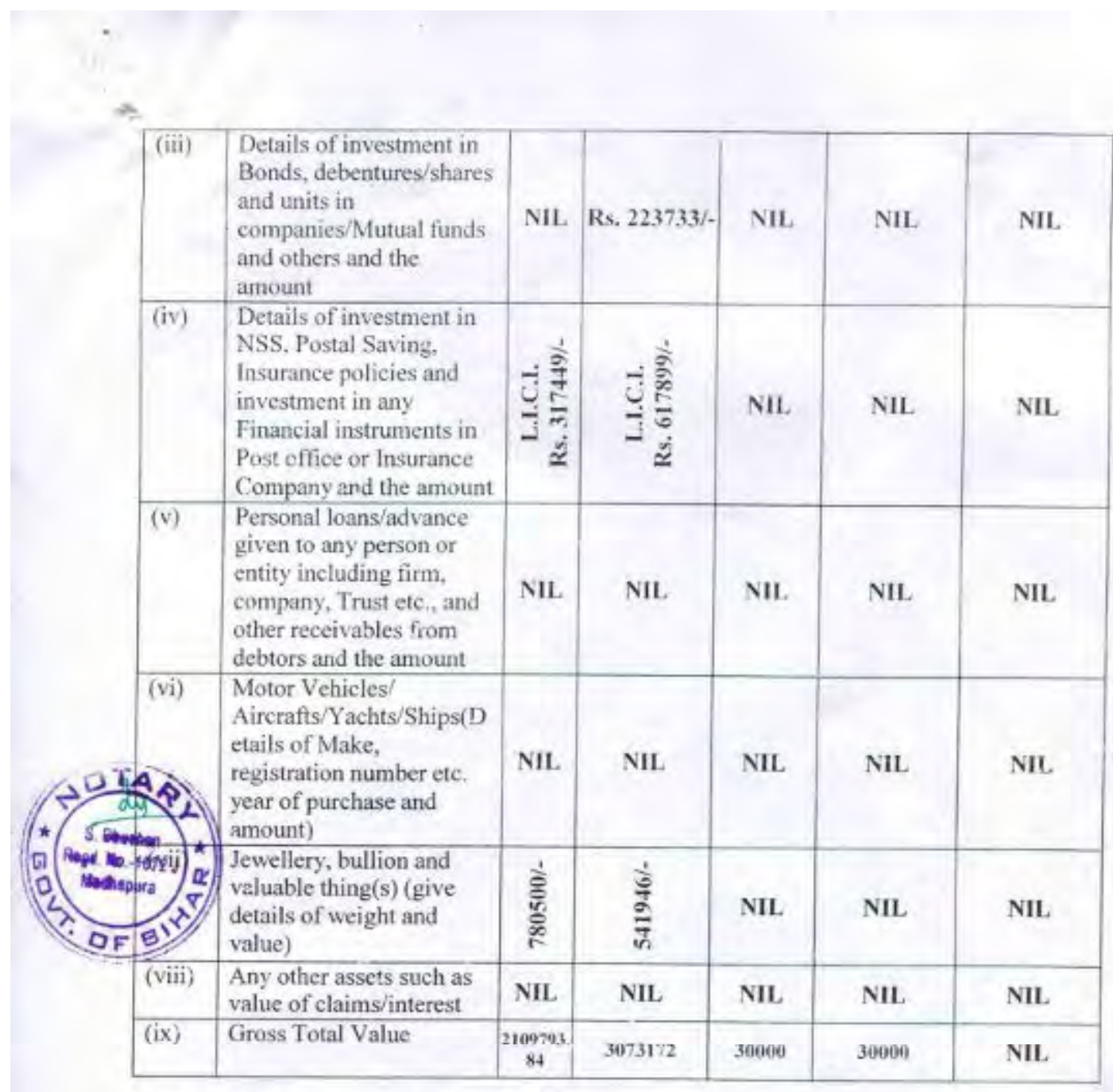

\section{B. Details of Immovable Assets:}

Note: 1. Properties in joint ownership indicating the extent of joint ownership will also have to be indicated

Note: 2. Each land or building or apartment should be mentioned separately in this format

\begin{tabular}{|l|l|c|c|c|c|c|}
\hline $\begin{array}{l}\text { S1. } \\
\text { No. }\end{array}$ & Description & Self & Spouse & Dependent-1 & Dependent-2 & Dependent-3 \\
\hline (i) & $\begin{array}{l}\text { Agricultural Land } \\
\text { Location(s) Survey } \\
\text { number(s) }\end{array}$ & $\begin{array}{c}\text { Khats No.99 } \\
\text { Khata No. } \\
113\end{array}$ & Nil & Nil & Nil \\
\cline { 2 - 7 } & $\begin{array}{l}\text { Area (total } \\
\text { measurement in acres) }\end{array}$ & Nil & $0.1722 ~ H t r$. & Nil & Nil & Nil \\
\hline $\begin{array}{l}\text { Whether inherited } \\
\text { ppaperty (Yes or No) }\end{array}$ & Nil & Nil & Nil & Nil \\
\hline
\end{tabular}




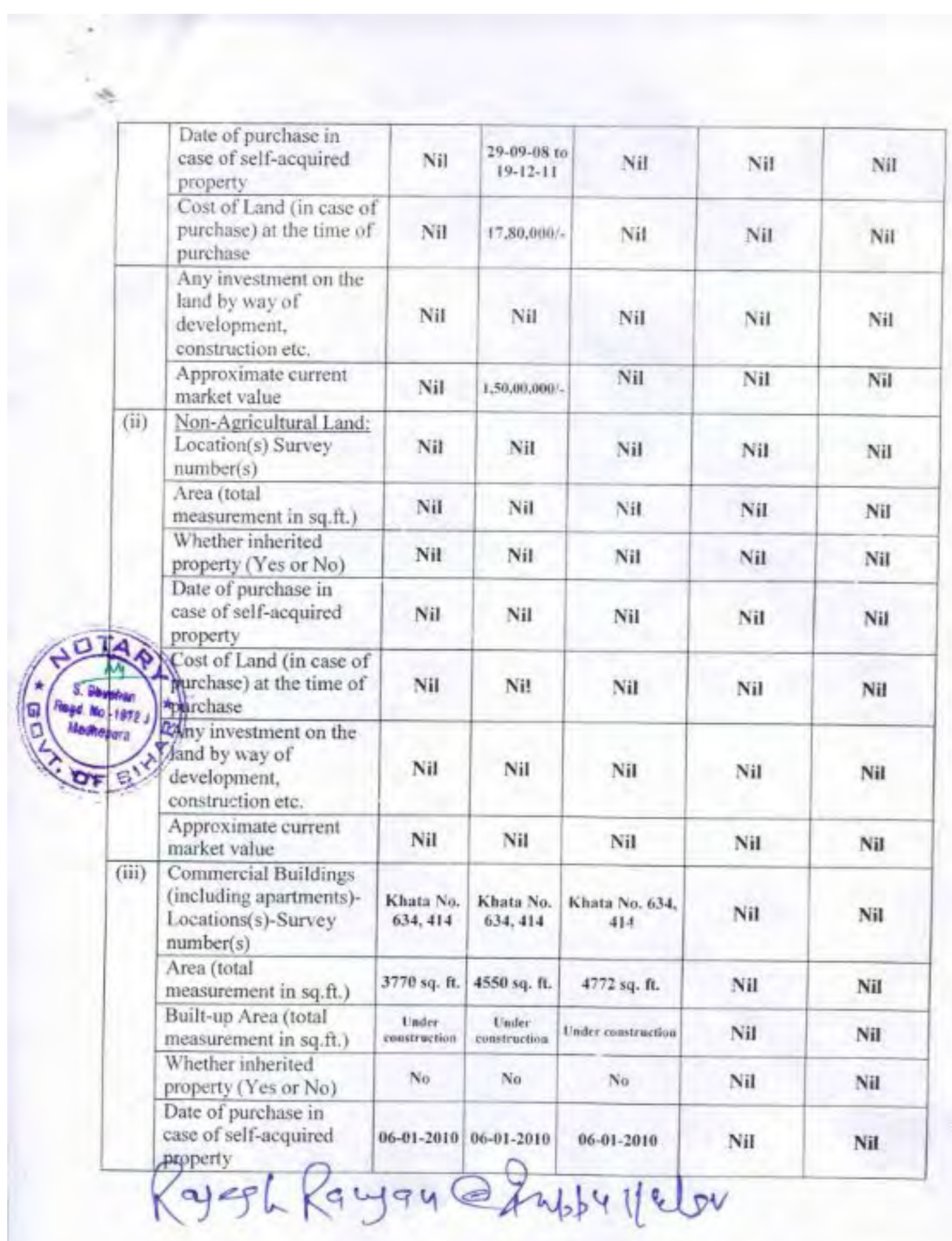




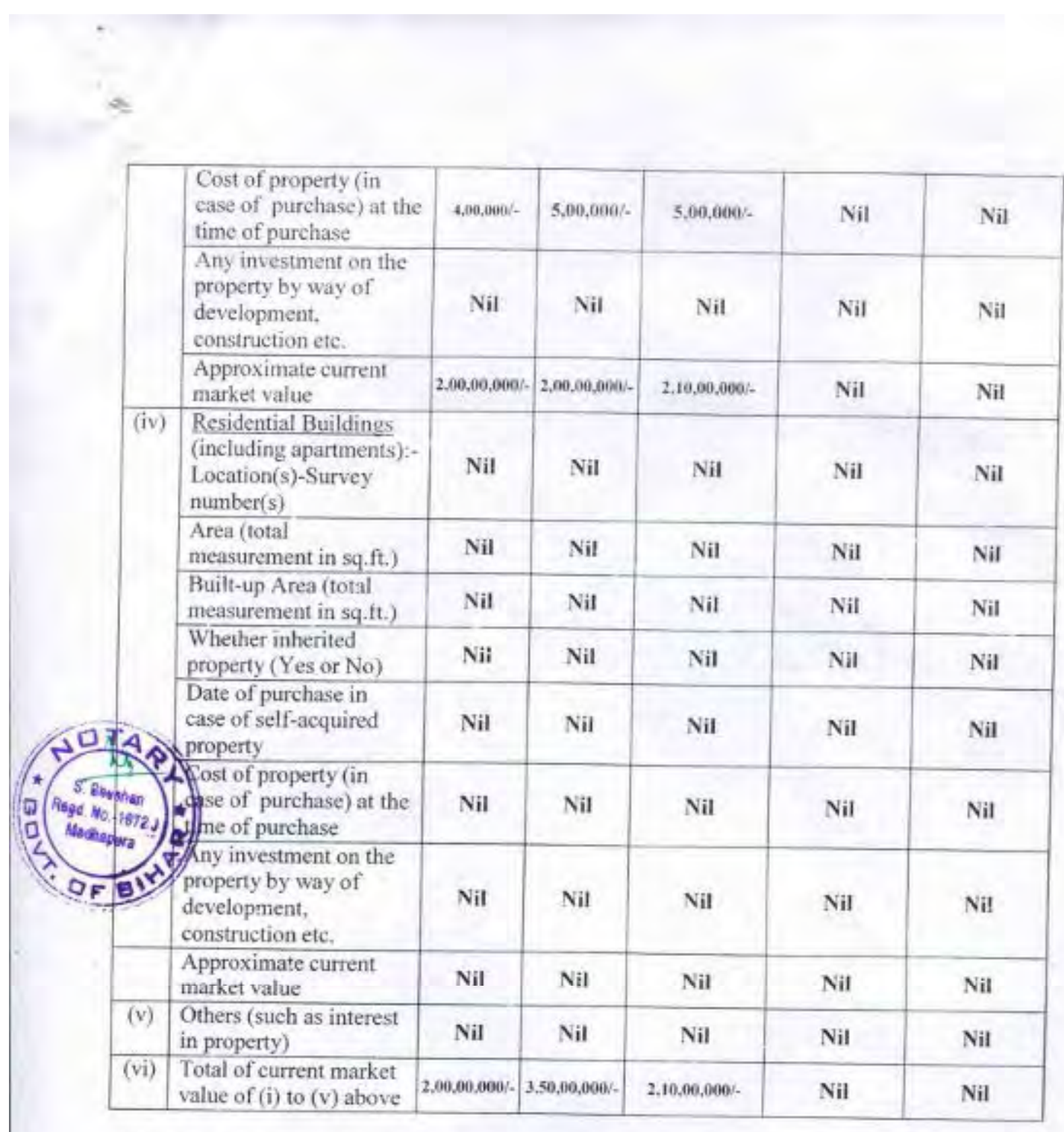

(8) 1 give herein below the details of liabilities/dues to public financial institutions and government:-

(Note: please give separate details of name of bank, institution, entity or individual and amount before each iterp

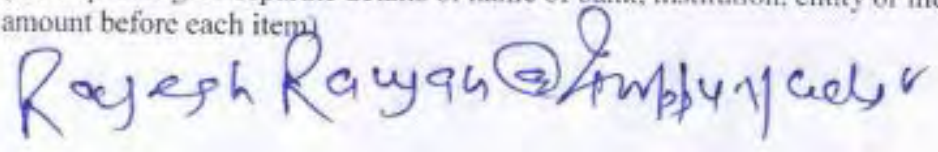




\begin{tabular}{|c|c|c|c|c|c|c|}
\hline S.No & Description & Self & Spouse & Dependent-1 & Dependent-2 & Dependent-3 \\
\hline \multirow[t]{4}{*}{ (i) } & $\begin{array}{l}\text { Loan or dues to } \\
\text { Bank/financial } \\
\text { institution(s) } \\
\text { Name of the Bank of } \\
\text { financial institution, } \\
\text { Amount outstanding, } \\
\text { Nature of Loan } \\
\end{array}$ & Nil & Nil & Nil & Nil & Nil \\
\hline & $\begin{array}{l}\text { Loan or dues to any other } \\
\text { individuals/entity other } \\
\text { than mentioned above } \\
\text { Name(s), Amount } \\
\text { outstanding, nature of loan }\end{array}$ & Nil & Nil & Nil & Nil & Nil \\
\hline & Any other liability & Nil & Nil & Nil & $\mathrm{Nii}$ & Nil \\
\hline & Grand total of liabilities & Nil & Nil & Nil & Nil & Nil \\
\hline \multirow[t]{11}{*}{ (ii) } & $\begin{array}{l}\text { Government ducs: } \\
\text { Dues to departments } \\
\text { dealing with Government } \\
\text { accommodation }\end{array}$ & $3,35,318:-$ & Nil & Nil & Nil & Nil \\
\hline & $\begin{array}{l}\text { Dues to department dealing } \\
\text { 4ij supply of water }\end{array}$ & $\begin{array}{c}\text { ANMEXURE } \\
-3\end{array}$ & Nil & Nil & Nil & Nil \\
\hline & $\begin{array}{l}\text { D2 } 2 \text { p department dealing } \\
\text { havit sypply of electricity }\end{array}$ & $6.20,988 /-$ & Nil & Nil & Nil & $\mathrm{Ni!}$ \\
\hline & 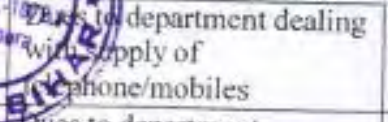 & $\begin{array}{c}\text { ANrExuef } \\
-3\end{array}$ & Nil & Nil & Nil & Nil \\
\hline & $\begin{array}{l}\text { Dies to department } \\
\text { dealing with government } \\
\text { transport (including } \\
\text { aircrafts and helicopters) }\end{array}$ & Nil & Nil & Nil & Nil & Nil \\
\hline & Income tax dues & NIL & Nil & Nil & Nil & Nil \\
\hline & Wealth tax dues & Nil & Nil & Nil & Nil & Nil \\
\hline & Service tax dues & NIL & Nil & Nil & Nil & Nil \\
\hline & $\begin{array}{l}\text { Municipal/Property Tax } \\
\text { dues }\end{array}$ & Níl & Nil & Nil & Nil & Nil \\
\hline & Sales tax dues & Nit & Nil & Nil & Nil & Nil \\
\hline & Any other dues & Nil & Nil & Nil & Nil & Nil \\
\hline (iii) & $\begin{array}{l}\text { Grand total of all } \\
\text { Government dues }\end{array}$ & $|9,56,306 /-|$ & Nil & $0^{\prime}$ & Nil & NiI \\
\hline
\end{tabular}


2

\begin{tabular}{|l|l|l|l|l|l|l|}
\hline (iv) \begin{tabular}{|l|l|l|} 
Whether any other \\
liabilities are in dispute, if \\
so, mention the amount \\
involved and the authority \\
before which it is pending
\end{tabular} & Nil & Nil & Nil & Nil & Nil \\
\hline
\end{tabular}

(9) Details of profession or occupation.

(a) Self SOCIAL SERVICE \& POLITICS

(b) Spouse SOCIAL SERVICE \& POLIIICS

(10) My educational qualification is as under:-

GRADUATION From B. N. M. U. Madhepura 1989 (Give details of highest

School/University education mentioning the full form of the

certificate/diploma/degree course, name of the School/College/University and the

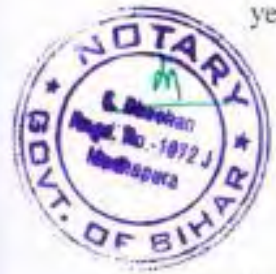

year in which the course was completed.)

\section{PART-B}

(11) ABSTRACT OF THE DETAILS GIVEN IN (1) TO (10) OF PART-A:

\begin{tabular}{|c|c|c|}
\hline 1. & Name of the Candidate & $\begin{array}{l}\text { Sh,/SmL/kum. } \\
\text { RAJESH RANJAN @ PAPPU YADAV }\end{array}$ \\
\hline 2. & Full postal address & $\begin{array}{l}\text { RANJAN NIKETAN COURT STATION AREA. } \\
\text { P.S. K. HAT: DIST,- PURNEA BIHAR PIN - } \\
854361\end{array}$ \\
\hline 3. & $\begin{array}{l}\text { Number and name of the } \\
\text { constituency and State }\end{array}$ & 13 MADHEPURA BIHAR \\
\hline 4. & $\begin{array}{l}\text { Name of the political party which set } \\
\text { up the candidate (otherwise write } \\
\text { 'Independent') }\end{array}$ & RASHTRIYA JANATA DAL \\
\hline \multirow[t]{2}{*}{5.} & $\begin{array}{l}\text { (i) Total number of pending cases } \\
\text { where charges have been framed by } \\
\text { the Court for offences punishable } \\
\text { with imprisonment for two years or } \\
\text { more }\end{array}$ & 17 \\
\hline & $\begin{array}{l}\text { (ii) Total number of pending cases } \\
\text { where the court(s) have taken } \\
\text { cognizance [other than the cases } \\
\text { mentioned in jtem (i) above] }\end{array}$ & 7 \\
\hline
\end{tabular}




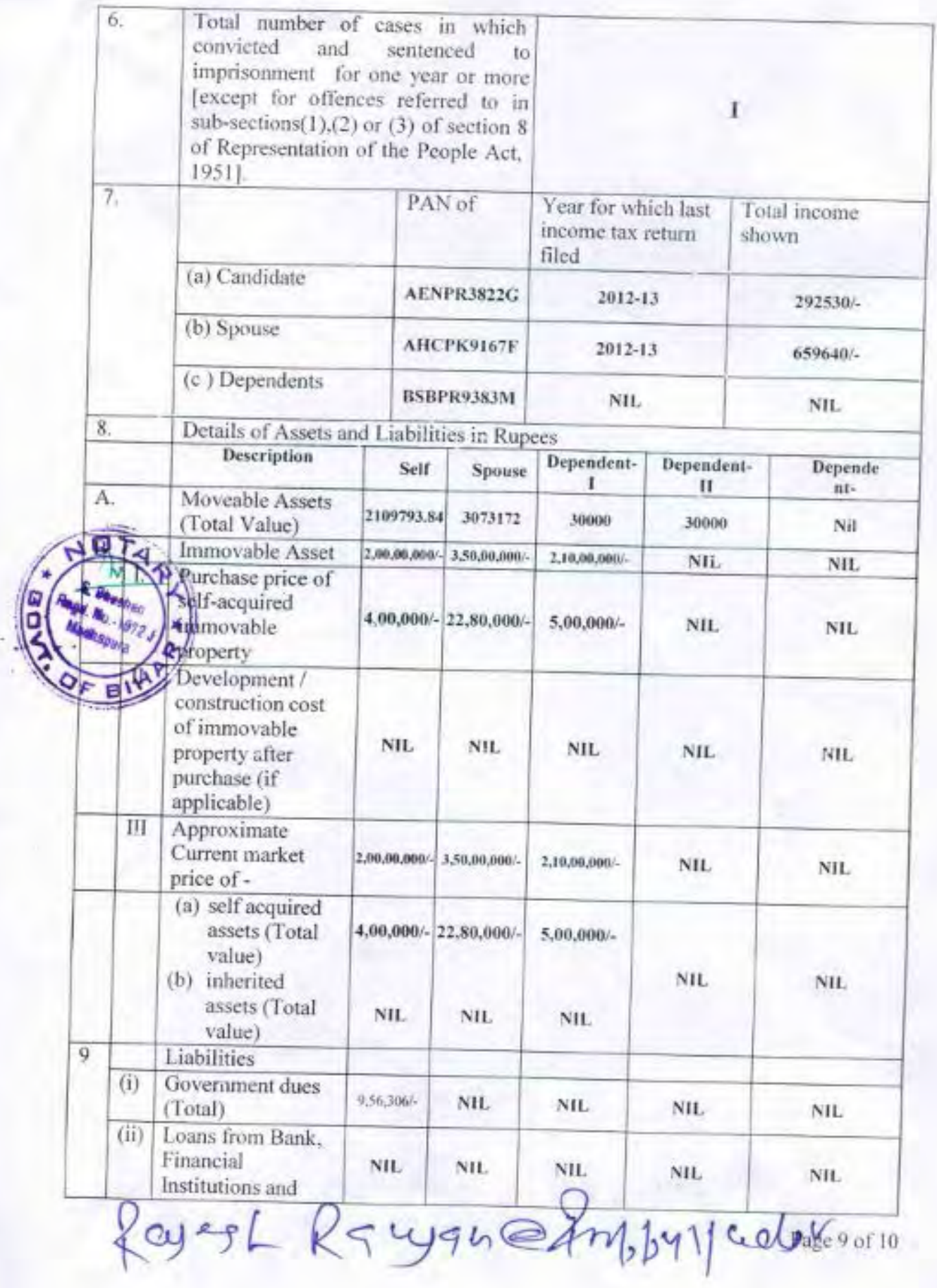




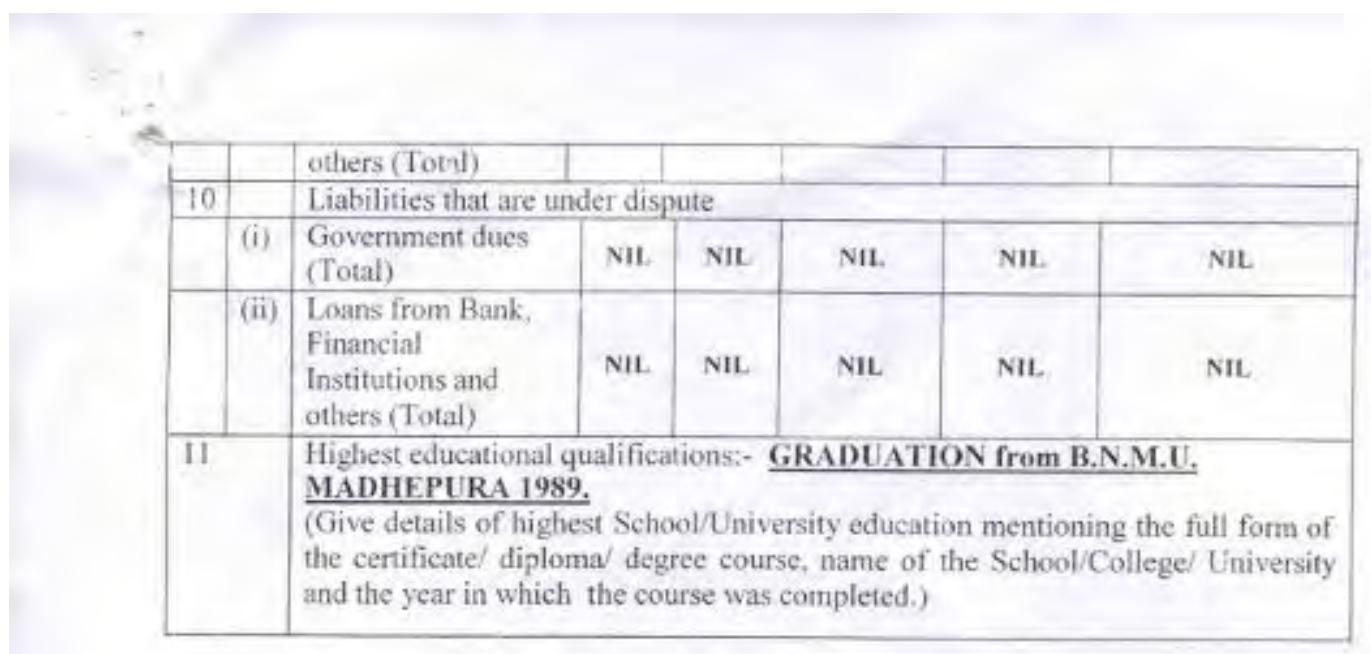

\section{VERFICATION}

I, the deponent, above named, do hereby verify and declare that the contents of this affidavit are true and correct to the best of my knowledge and belief and no part of it is false and nothing material has been concealed there from. I further declare that:-

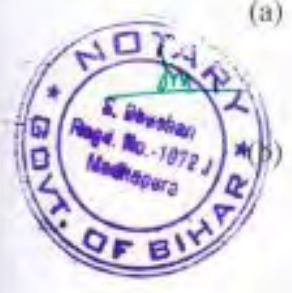

There is no case of conviction or pending case against me other than those mentioned in items 5 and 6 Part $\mathrm{A}$ and $\mathrm{B}$ above;

I, my spouse, or my dependents do not have any asset or liability, other than those mentioned in item 7 and 8 of Part A and items 8,9 and 10 of Part B above.

Verified at Machethur a This the $71<$. Day of. Absil $201 \mathrm{C}$

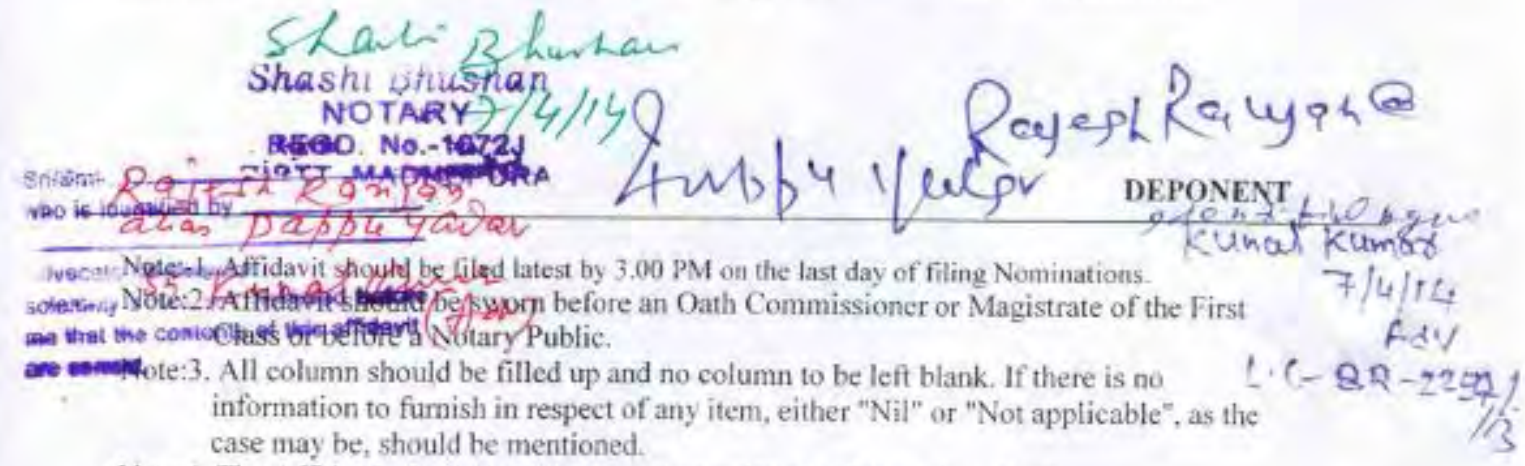

Note:4. The Affidavit should be either typed or written legibly and neatly." 


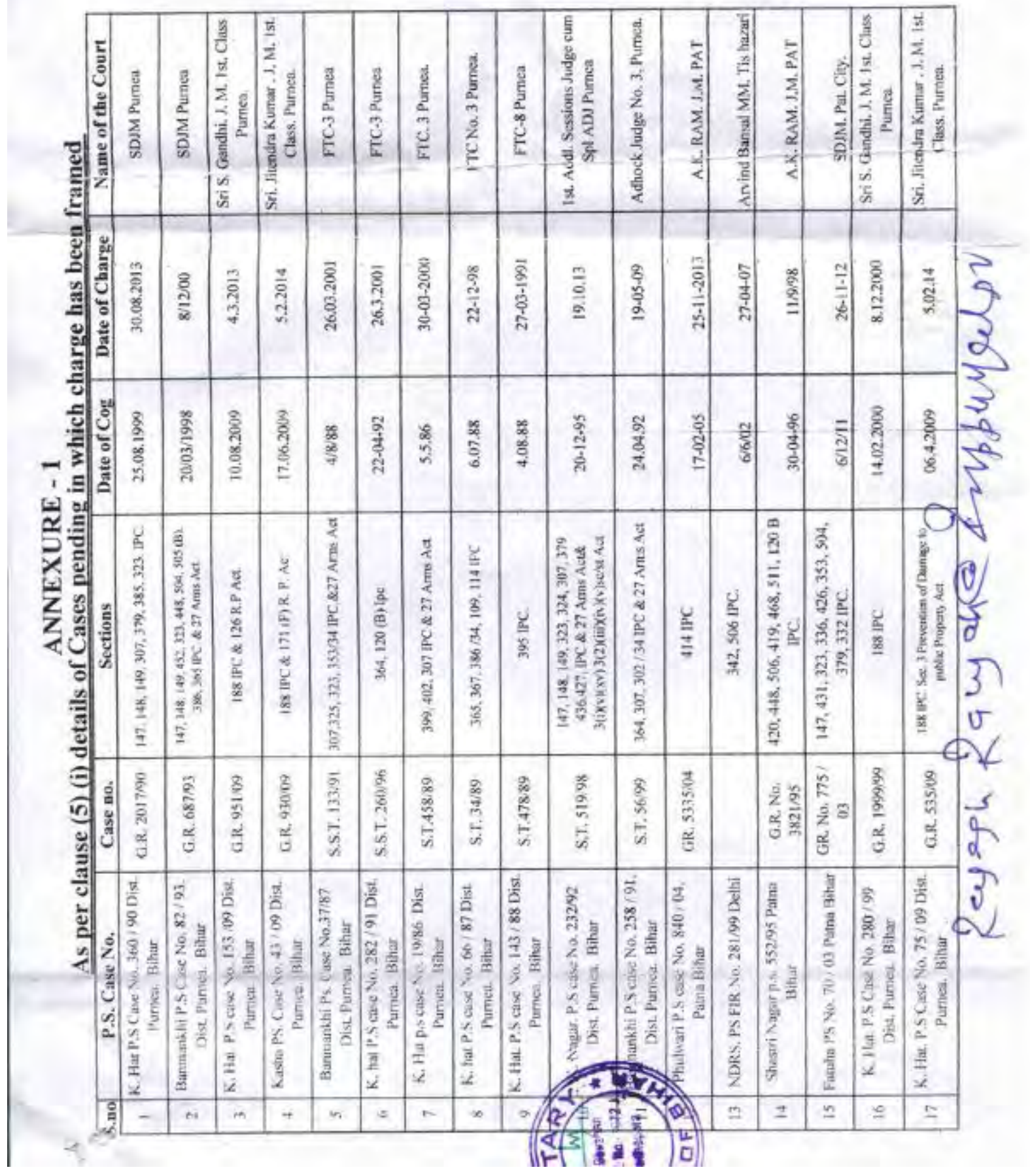




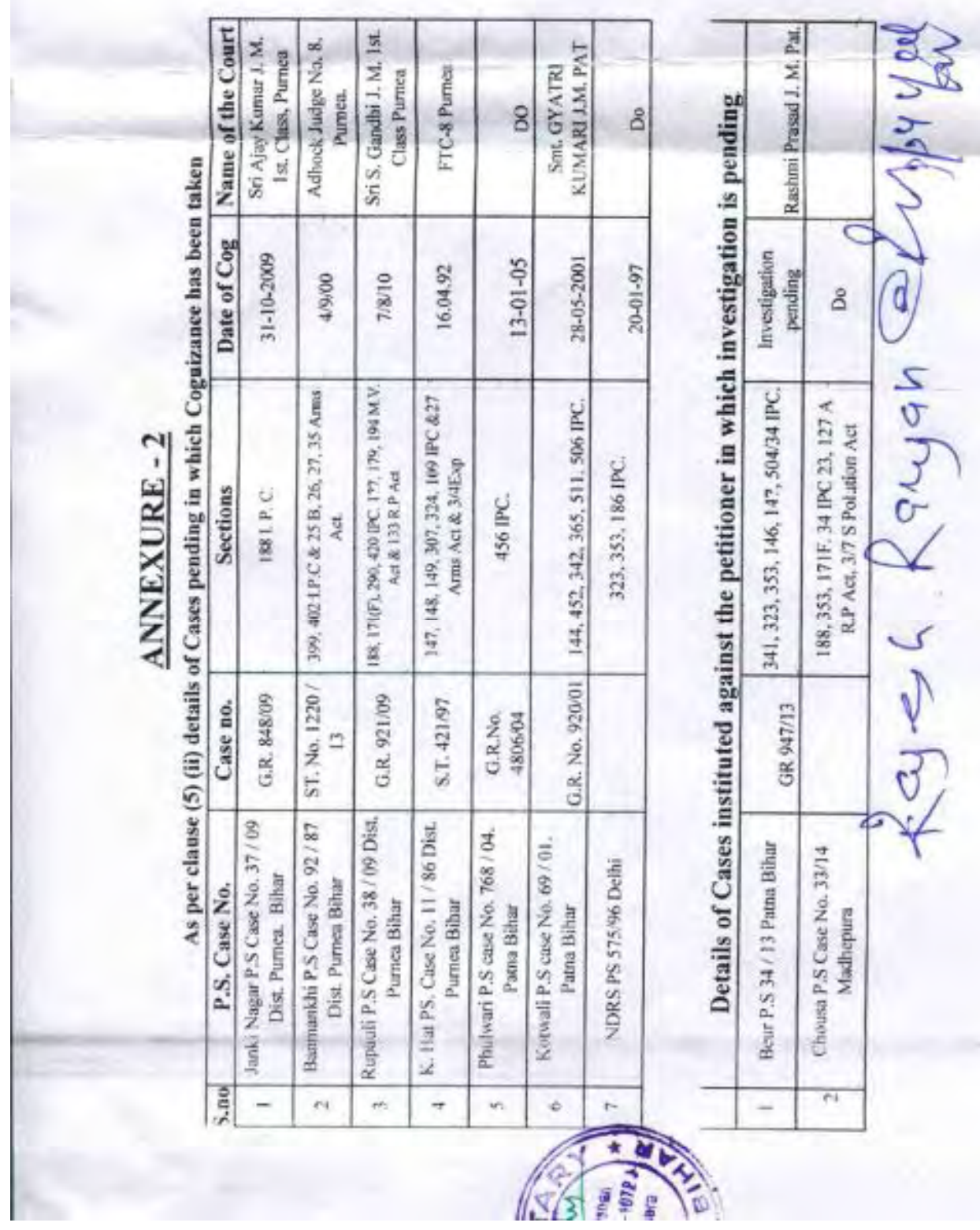




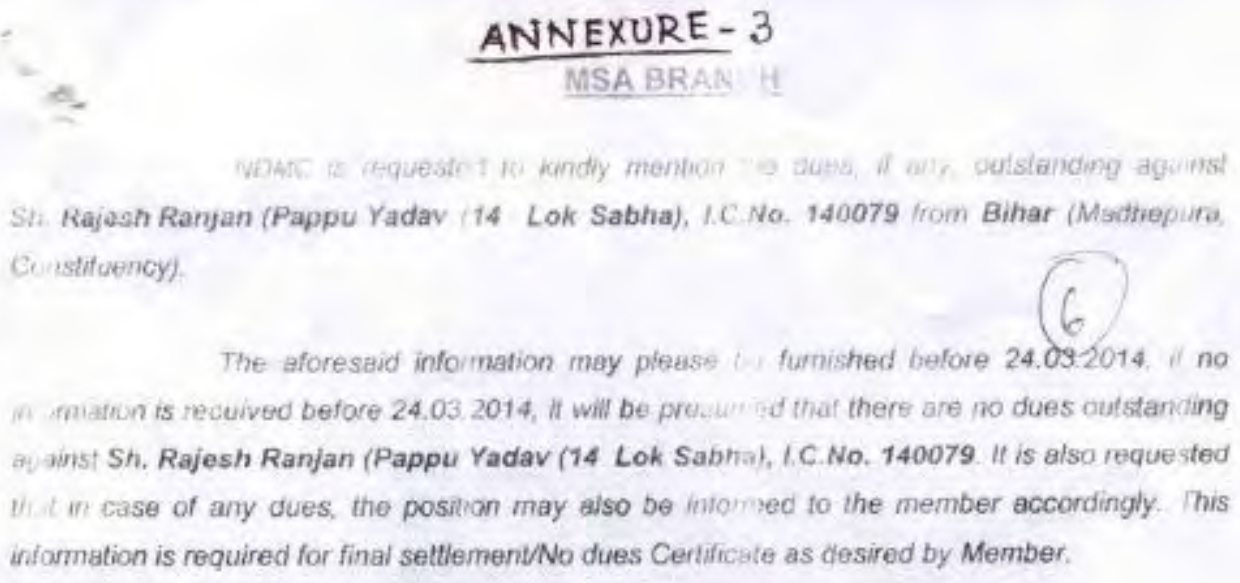
In matnon is recuived befare 24.03.2014, it will be pre.uni gd that there are po dues outstanding ay ainst Sh. Rajesh Ranjan (Pappu Yadav (14 Lok Sabha), I.C. No. 140079. It is alsa reque sted 1) tin case of any dues, the position may aiso be intomed to the member accondingly. This information is required for final seltlement/No dues Cerlificate as desired by Member.

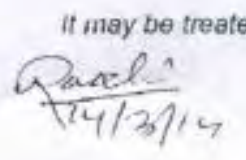

\section{Parh LibraruPLB]}

Comouter (hw\&sw) Management Branch (PLB)

Estate Oflice (602 PHA)

CPl Ceal Near Rly Reservation. PHI

NOWC TISPHA)

MTNLESNL $(5,0$, PHA)

Publicatton Branch (PH]

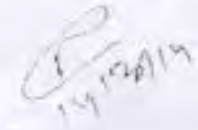

$$
\begin{aligned}
& 64028632350 \\
& 64029641697 \\
& 640286522136 \\
& 6405250 \text { 5te } \\
& 6405251 \quad 606 \\
& 6300488 \quad 98 \\
& 6.200578 \quad 3345 \\
& 6400694, \quad 246 n- \\
& \text { clolde } 6300858 \quad 108924 \cdot n \\
& 6,28,988
\end{aligned}
$$

LLAISON OFFICE: NDMC 314, PARLIAMENT HOUSE ANNEXE

\section{Ref as above} NEW DELHI

De. 15.03 .2014

A sum of $₹ 6,20,988.00$ is outstanding on account of electric / water charges against Sh. Raujesh Ranjan (Pappu Yadav), Hon'ble MP (14th Lok sabha) I.C. No 140079. FAOE.

SOLLPH]

M.S.A Branch (LS)

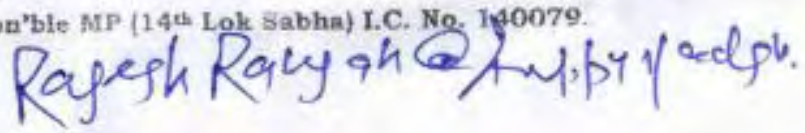

